Revista Complutense de Historia de América ISSN: 1132-8312

http://dx.doi.org/10.5209/RCHA.61082

\title{
Disputas territoriais e o financiamento da empresa missionária jesuítica na Amazônia espanhola
}

\author{
Francismar Alex Lopes de Carvalho ${ }^{1}$
}

Recibido: 4 de noviembre de 2016 / Aceptado: 9 de mayo de 2017

Resumo. Este artigo analisa as formas por meio das quais os jesuítas obtinham recursos materiais e humanos para as missões que empreenderam na Amazônia espanhola. Entre 1638 e 1767, os inacianos estiveram a cargo das reduções de Maynas, localizadas nas franjas orientais da Audiência de Quito. Nessas missões, não lograram os religiosos instalar um sistema produtivo viável, de modo que suas atividades foram, em grande medida, financiadas com donativos de particulares, recursos transferidos de colégios próximos e remessas das tesourarias reais, que somente foram regularizadas a partir de 1716. Entender por que os jesuítas tardaram tanto tempo em obter um auxílio permanente da Real Hacienda e de que maneira conseguiram convencer o Consejo de Indias é o objetivo principal deste trabalho. $\mathrm{O}$ recrutamento e a manutenção do pessoal missionário terão dependido do jogo de forças entre interesses econômicos locais, a atuação dos procuradores da Companhia de Jesus ante o Consejo de Indias e a estratégia defensiva de Madrid diante do avanço territorial dos portugueses.

Palavras-chave: Missões jesuíticas; procuradores; financiamento; Maynas; Amazônia; séculos XVII-XVIII

\section{[en] Territorial Disputes and the Financing of the Jesuit Missionary Enterprise in Spanish Amazonia}

\begin{abstract}
This article examines the ways in which Jesuits obtained material and human resources for their missions in Spanish Amazonia. Between 1638 and 1767, Jesuits were in charge of the Maynas reductions, located on the eastern fringes of the jurisdiction of the Audiencia de Quito. In these missions, Jesuits failed to install a viable production system. Their activities were largely financed through private donations, funds transferred from nearby Colegios, and remittances from royal treasuries, which were settled in 1716. This study explores both why it took so long for the Jesuits to secure permanent aid from the Royal Treasury and what strategies they used to convince the Council of the Indies to fund their endeavors in the Spanish Amazonian region. I argue that the recruitment and retention of missionary personnel depended on power struggles between local economic interests, the pressure of the Jesuit prosecutors on the Council of the Indies, and Spain's defensive strategy against Portuguese territorial encroachment.
\end{abstract}

Keywords: Jesuit Missions; prosecutors; financing; Maynas; Amazonia; 17-18th Centuries.

Sumario. 1. Introdução. 2. Nas fronteiras do Real Patronato. 3. Origens dos recursos. 4. O sínodo anual dos missionários. 5. O comércio dos itens produzidos nas missões. 6. A falta de missionários. 7. Considerações finais. 8. Referências bibliográficas.

1 Professor Adjunto do Departamento de História da Universidade do Estado do Rio de Janeiro (Brasil)

E-mail: francismardecarvalho@gmail.com 
Cómo citar: Lopes de Carvalho, F. A. (2018) Disputas territoriais e o financiamento da empresa missionária jesuítica na Amazônia espanhola, en Revista Complutense de Historia de América 44, 115-142.

\section{Introdução}

No império espanhol, a percepção generalizada era a de que à Coroa cumpria a obrigação de custear o envio de missionários à América, assim como sua manutenção, durante os primeiros dez ou vinte anos, por meio do pagamento de côngruas ou sínodos (que podiam variar de 200 a 400 pesos anuais para cada religioso). Encargo incontornável se se tratassem de missões entre índios ainda independentes, que viviam nas regiões de fronteira, comumente referidos como "índios bárbaros", em oposição aos índios já tributários. Esperava-se, ainda, que quando essas missões se convertessem em doutrinas, os índios seriam empadronados e obrigados a pagar o tributo, com o qual custeariam os ensinamentos que lhes eram ministrados ${ }^{2}$.

Este artigo analisa as formas por meio das quais os jesuítas obtinham recursos materiais e humanos para as missões que empreendiam na Amazônia ocidental. Encontram-se mais bem estudadas as dificuldades de variado jaez que marcaram o trabalho dos inacianos nessas regiões, como a grande diversidade linguística e cultural, o elevado número de reduções, a falta de missionários e a influência de escravistas portugueses ${ }^{3}$. A análise de uma documentação mais variada, localizada em arquivos de diversos países, permitiu iluminar outros matizes que não puderam ser contemplados por Ann Golob, cuja tese de doutorado é o trabalho pioneiro sobre o tema do financiamento das missões de Maynas ${ }^{4}$. Para as missões do Paraguai, de Mojos e de Chiquitos, há estudos, antigos e recentes, que desenvolveram questões ligadas ao modo de financiamento do trabalho missionário ${ }^{5}$. Os estudiosos que se dedicaram ao

$2 \quad$ Borges Morán, 1992: 426; Brading, 1983: 8-11; Weber, 2007: 162; Clossey, 2008: 162-173. Essas responsabilidades do poder central eram parte constituinte do Real Patronato que, entre suas atribuições, contava a de que a provisão de missionários para o Novo Mundo estivesse sob a direção do Consejo de Indias. Em suas ordenanças àquele conselho, Felipe II afirmava: "Según la obligación y cargo con que somos Señor de las Indias, ninguna cosa deseamos más que la publicación y ampliación de la Ley Evangélica y la conversión de los Indios a nuestra Santa Fe Católica". Assim, ficava aquele tribunal encarregado de "proveer y poner ministros suficientes para ello". Liv. 2, Tít. 2, Lei 8a, in: Recopilación, 1943 [1681], t. 1: 233; cf. Bayle, 1936: 153. Na maior parte dos casos, como a Real Hacienda não pretendia manter as despesas por mais de vinte anos, após esse período de trabalho missionário considerava-se que os índios já estavam inseridos na cultura cristã, e as reduções se convertiam em doutrinas. Borges Morán, 1992: 434.

3 Esses temas são desenvolvidos nos estudos monográficos disponíveis sobre as missões jesuíticas de Maynas, que infelizmente são poucos. O tema da influência dos portugueses tem sido desenvolvido por: Sweet, 1974: 141 e 466; Gómez González, 2011: 65 et seq.; Herzog, 2015: 84 et passim. Sobre a diversidade linguística e cultural e a organização das missões, ver, entre outros, os trabalhos de: Stephan, 2000; Downes, 2005; Lopes de Carvalho, 2016.

4 Golob, 1982.

5 Sem pretender ser exaustivo, para o caso das missões de Guaranis, o estudo de Sarreal (2014: 86) fornece um panorama atualizado sobre questões econômicas e de financiamento, embora continuem relevantes os trabalhos de Mörner, 1968; Garavaglia, 1987; Carbonell de Masy, 1992. Sobre as missões de Chiquitos, o processo por meio do qual a Coroa espanhola decidiu assinalar um sínodo para os padres e as vicissitudes do envio de religiosos estão bem documentados em Tomichá Charupá, 2002. Em Radding, 2005, encontra-se uma discussão sobre aspectos econômicos dessas missões em comparação com as de Sonora. Um levantamento das inversões da Coroa espanhola em Mojos aparece em: Block, 1994: 67. Santamaría, em vários trabalhos, dedicou-se a questões econômicas relacionadas às missões de Mojos e Chiquitos (ver, por exemplo, Santamaría, 1987). 
tema do envio de religiosos para as missões americanas, clássico na historiografia espanhola, não descuidaram das províncias de Quito e Novo Reino de Granada, de modo que este artigo leva em consideração essas contribuições ${ }^{6}$. Os aspectos que são distintivos na abordagem aqui apresentada são, de um lado, a inserção do problema do financiamento no quadro mais amplo da política territorial da Coroa espanhola em relação ao espaço amazônico, em decorrência das disputas de limites com os domínios portugueses; e de outro, um exame mais atento em relação às prioridades da própria Companhia de Jesus, que, como se verá, apesar de ter recebido um número importante de religiosos no século XVIII, preferiu alocá-los em outras missões mais prósperas ou mantê-los no Colégio de Quito.

A formação de uma das mais importantes missões que os jesuítas estabeleceram na América do Sul, as missões de Maynas, principiou com a chegada dos padres Lucas de la Cueva e Gaspar Cujía à cidade de San Francisco de Borja, a mais oriental na jurisdição da Audiência de Quito, em fevereiro de 1638.

Em realidade, até fins do século XVI, a exploração de metal precioso animara a presença espanhola a oriente de Quito. Contudo, a diminuição da população indígena, em razão de epidemias, insurreições e fugas, e da quantidade do ouro extraído, levou ao desaparecimento das vilas de Logroño, Sevilla del Oro e Zamora. Outras cidades localizadas nas franjas da Amazônia, como Archidona, Ávila, Baeza, Moyobamba e San Francisco de Borja, mantiveram suas atividades econômicas, em grande medida dependentes da instituição da encomienda. Embora os jesuítas, em não raras ocasiões, tivessem que levantar queixas sobre correrías em que colonos capturavam índios das terras baixas, o comércio de Maynas com essas cidades continuará sendo fundamental para a permanência das missões (Figura 1) ${ }^{7}$.

Lucas de la Cueva e Gaspar Cujía davam, assim, prosseguimento ao trabalho missionário entre os índios amazônicos, interrompido por ocasião de haver desamparado a cidade de Borja os clérigos e outros religiosos mercedários e agostinhos, que se retiraram após uma revolta dos Maynas contra seus encomenderos ${ }^{8}$. De 1638 a 1660 , os inacianos realizaram intensas explorações no vale do rio Marañón e reduziram os grupos Maynas, Jeberos e Cocamas. Entre 1660 e 1700, a missão se expandiu às margens dos rios Curaray, Tigre e afluentes meridionais do Marañón. Finalmente, entre 1720 e 1767, fundaram a chamada "missão baixa", entre as sociedades Tupi dos rios Napo e médio Amazonas ${ }^{9}$.

6 A atuação dos procuradores jesuítas pode ser acompanhada em vários trabalhos que abordaram seu empenho em recrutar missionários ou obter privilégios e benefícios para as missões. Ver, entre outros: Aspurz, 1946: 251, Apéndice I; Zubillaga, 1953: 394-398, et passim; Mörner, 1968: 64-67; Borges Morán, 1977: 511-524; Galán García, 1995: 197 et seq.; Martínez-Serna, 2009: 182. Rey Fajardo possui uma extensa contribuição a respeito dos jesuítas que atuaram em Nova Granada (ver, em especial, Rey Fajardo, 2007: 427, et passim).

7 Sobre esse período inicial e a importância da encomienda nessas cidades, ver, entre outros: Rumazo González, 1946; Oberem, 1980; Newson, 1995; Taylor, 1999; Lane, 2002.

8 Información jurídica a instancia del P. Lorenzo Lucero. San Francisco de Borja, 23-IX-1683. Archivum Historicum Societatis Iesu [Itália] (doravante ARSI), Novi Regni et Quitensis (NR et Q), 15, i, f. 105. Cf. Relación dada por Don Pedro Vaca de la Cadena, gobernador de la provincia de los Maynas, al Dr. Antonio de Morga, presidente de la Real Audiencia de Quito. IV-1629. Archivo General de Indias [Espanha] (doravante AGI), Quito, 11, r. 3, n 37; Jouanen, 1941, vol. I: 328; Bayle, 1949: 12-13.

9 Descripción del país que debe comprehender el nuevo Obispado de misiones que se propone en Maynas, por Francisco Requena. Tabatinga, 12-III-1781. AGI, Quito, 241, nº 58, f. 22; Grohs, 1974: 124. 


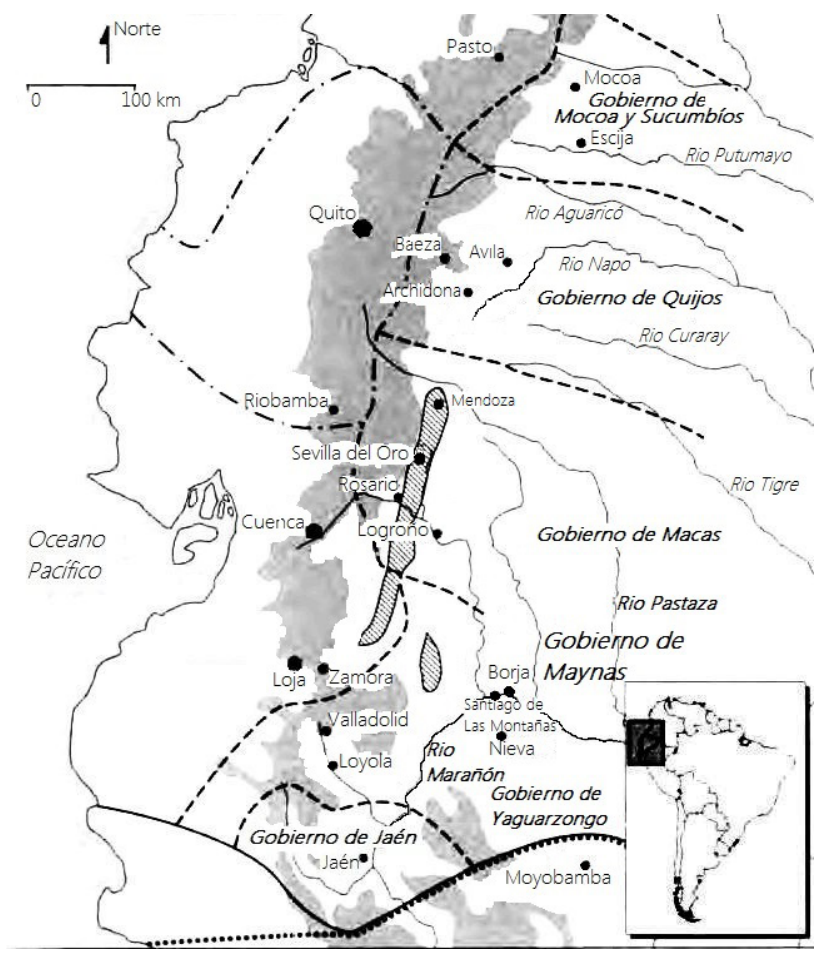

Figura 1. Piemonte Andino e Amazônia Ocidental, na jurisdição da Audiência de Quito, em meados do século XVII ${ }^{10}$.

Os missionários reconheciam que a falta de produtos de alto valor comercial, de cuja exportações pudessem sacar recursos para manter mais religiosos e ofertar mais ferramentas, roupas e avelórios aos índios, foi um fator decisivo que impediu que as missões avançassem como esperado ${ }^{11}$. Não é certo, contudo, que as missões de Maynas resultassem em um completo fracasso: o número de índios reduzidos passou de 7.966 almas em 28 pueblos, em 1719, às 11.281 almas, em 21 pueblos, em $1768^{12}$.

A dependência das missões de Maynas em relação à subvenção das tesourarias reais (cajas reales) envolvia uma série de problemas, que serão examinados neste trabalho. Como indicava uma Cédula de 1660, que ordenava o pagamento de mil pesos de ajuda de custo aos missionários do Marañón, o Consejo de Indias estava

10 Fonte: Elaboração própria a partir de mapa publicado por Taylor, 1999: 212. O tracejado indica a delimitação das governações; o pontilhado, a da Audiência de Quito; e a linha contínua, a do bispado de Quito.

11 Enrique Richter a José Antonio de la Rentería. La Laguna, 19-IX-1686. ARSI, NR et Q, 15, i, ff. 114-114v; Copia de carta del Padre Samuel Fritz. Pará, 1691. AGI, Quito, 4, f. 328; Wenceslao Breyer a su hermano, sacerdote jesuita en Praga. La Laguna, 18-VI-1699, in: Matthei, 1969, vol. I: 254; Chantre y Herrera, 1901 [anterior a 1801]: 616-618. Ainda sobre o problema da escassez de recursos, ver: Reeve, 1993: 127-134; Medina Rojas, 1999: 316 et passim; Codina, 2005: 250-253.

12 Catalogus Missionum Gentilium Societatis Jesu in Provincia Quitensi. Missiones Maynarum fluvii Marañon et Amazonas. 1719. Biblioteca Nazionale Vittorio Emanuele II [Itália], Ms. Gesuitico 1249/1 (3378), all. I; Censo de las misiones de Maynas. Archidona, 15-II-1768. Biblioteca Nacional de España [Espanha], mss/17614, ff. 35 [f. 75]-41 [81]; ver também: Golob, 1982: 203. Para efeitos de comparação, em 1746, as missões de Chiquitos contavam com 14.701 moradores, segundo o censo de Francisco Xavier de Palacios; ver seu informe: Carta del Oidor de Charcas, Francisco Xavier de Palacios, al rey. La Plata, 22-VIII-1746. AGI, Charcas, 207. 
informado de "ser las tierras de estas naciones sumamente miserables"13. As produções de Maynas incluíam, entre outros itens, cacau, cera, salsaparrilha, pimenta (ají), urucu (achiote), tabaco, canela, estoraque, algodão e algum ouro em pó, mas não em quantidades razoáveis ${ }^{14}$. Contudo, demorou quase oitenta anos para que a Coroa decidisse financiar com maior regularidade aquele empreendimento, ao conceder, em 1716, a cada missionário, a côngrua anual de 200 pesos, pagos juntamente com outras ajudas de custo das cajas reales ${ }^{15}$. Ao passo que outras missões alcançavam a autossuficiência, embora os padres também recebessem sínodos anuais, em Maynas, segundo estimou Golob, a ajuda da Real Hacienda totalizava três quartos do orçamento das missões ${ }^{16}$.

Por que a Coroa espanhola demorou tanto tempo em financiar regularmente as missões amazônicas? Que papel tiveram os jesuítas em convencer o Consejo de Indias a conceder os recursos materiais e humanos necessários, tendo em vista a pouca utilidade econômica que aquelas terras traziam à Real Hacienda? Por que, apesar da claudicante ajuda das caixas reais, os missionários que atuaram na Amazônia foram sempre insuficientes em relação à magnitude do trabalho a que se propunham?

$\mathrm{O}$ estudo dessas questões permite compreender a complexidade das relações entre funcionários coloniais, poderes locais e missionários; e verificar a diversidade de interesses entre as estratégias territoriais do poder central e da Companhia de Jesus. Como estudos recentes têm mostrado, a opção pela "missão" não era de modo algum algo "natural" entre os religiosos jesuítas, e houve um consistente esforço, durante o generalato do padre Acquaviva (1581-1615), no sentido de expandir as chamadas "misiones a infieles" ${ }^{7}$. Este trabalho argumenta que as limitações impostas ao desenvolvimento das missões jesuíticas na Amazônia espanhola foram decorrentes, em grande medida, da oposição entre perspectivas locais sobre as vantagens econômicas imediatas daqueles territórios e a estratégia defensiva territorial da Coroa. A tensão entre essas duas perspectivas constitui o eixo desta discussão.

A primeira parte deste estudo mostra como a Amazônia ocidental foi vista com relativa indiferença pelas autoridades coloniais, inclusive por Madrid, até a década de 1710, quando os avanços portugueses, denunciados incansavelmente pelos jesuítas, operaram uma mudança de visão, e levaram a que a Real Hacienda passasse a financiar regularmente o trabalho dos missionários.

A segunda parte analisa o modo como eram obtidos os recursos para o financiamento das missões por parte da Companhia de Jesus, de particulares e da Coroa, e os esforços empreendidos pelos padres para encontrar algum item de alto valor econômico que permitisse a autossuficiência de Maynas.

Embora essas tentativas tivessem fracassado, nem os jesuítas pretendiam abandonar aquela jurisdição, nem o poder central podia deixar aberta uma porta que conduziria os portugueses diretamente ao Peru. Assim, na terceira parte deste estudo,

13 Real Cédula aos oficiais da Real Hacienda da cidade de Quito. Madrid, 28-VIII-1660. AGI, Santa Fe, 983, f. 1v.

14 La Camara de Yndias: representa a VM lo que se le ofrece en cuanto a la instancia que hace Don Juan Joseph Sánchez de Orellana. Madrid, 22-VI-1739. AGI, Quito, 104, f. 3v; Descripción de la Provincia de Quito. Año de 1754, Marqués de Salva Alegre. Quito, 13-IX-1754. AGI, Quito, 220, nº 1, ff. 52v-53.

15 Real Cédula aos oficiais da Audiência de Quito. Madrid, 31-XII-1716. AGI, Santa Fe, 983 (também em: AGI, Quito, 113, ff. 351-354v, ff. 355-358); Plan y relación de todas las situaciones salarios y sueldos a misioneros en las cajas de Quito. Quito, 20-V-1740. AGI, Quito, 134, n 43a, f. 17v.

16 Golob, 1982: 229-231; ver também: Jouanen, 1941, vol. I: 370; Reeve, 1993: 127.

17 Broggio, 2004: 61-63; Maldavsky, 2012: 87 et passim. 
procura-se mostrar como os jesuítas trabalhavam com essa ambiguidade: embora a Real Hacienda custeasse o envio regular de missionários para aquela província, os jesuítas preferiam manter a maioria no Colégio de Quito, capital em que os inacianos contavam com importantes haciendas e obrajes, ao passo que destacavam apenas o mínimo necessário para o trabalho de evangelização na floresta ${ }^{18}$.

Desse modo se compreende como o desenvolvimento das missões jesuíticas na Amazônia esteve limitado pela contradição entre interesses econômicos locais e estratégias imperiais de controle territorial. Se, no caso do Paraguai, os territórios eram simultaneamente vantajosos do ponto de vista econômico e estratégico, na Amazônia as incertezas sobre as potencialidades e vantagens dos produtos da floresta não forneceram um impulso tão importante para a consolidação dos estabelecimentos quanto as disputas territoriais com os rivais lusitanos ${ }^{19}$.

\section{Nas fronteiras do Real Patronato}

Em um informe sobre o fruto que os padres da Companhia sacavam de suas missões amazônicas, enviado em 1662, o bispo de Quito, Alonso de la Peña Montenegro, apresentava um quadro sóbrio. Capelas havia, mas pequenas, e de palha, ao modo de choças, e a elas davam o título de igrejas, "pudiendo tener solamente este nombre la de d.ha ciud.e de Borja, que hallaron hecha, $[y]$ otra que fundaron en un paraje que llaman Jeberos". Parecia-lhe justo, contudo, que Companhia começasse a pagar o dízimo, pois "la tierra aunque no es de la más fértil, no deja de llevar algunos géneros buenos y los frutos suficientes para el sustento de los que la habitan"20.

As autoridades coloniais espanholas por muito tempo viram com indiferença os avanços portugueses sobre regiões que consideravam desprovidas de interesse econômico, e só tardiamente, em princípios do século XVIII, e não sem relutância, atentaram para o problema. Em seus escritos, os jesuítas enfatizaram a contrariedade das autoridades castelhanas em defender a Amazônia. Não vem ao caso agora interrogar por que o padre Samuel Fritz, em 1689, empreendeu uma viagem das missões de Maynas ao Pará ${ }^{21}$. O fato é que, conduzido de volta à redução de Omaguas pelos lusitanos de Belém e São Luís, esse jesuíta nascido na Bohemia presenciou com consternação a cerimônia de posse daquelas terras, conduzida pelo cabo da expedição, em nome da Coroa de Portugal. Já em 1692, Fritz foi a Lima com o objetivo de convencer o vice-rei a reforçar a presença espanhola na Amazônia. O padre obteve como resposta que aquelas regiões não traziam benefício algum à Coroa e, portanto, não valiam o esforço de defendê-las. Fritz registrou em seu diário o teor da réplica do Conde de la Monclova, para quem "aquellos bosques en lo temporal no fructifican al

18 Sobre as empresas dos jesuítas em Quito, ver: Cushner, 1982.

19 Para além das exportações de erva-mate, tecidos (de algodão e de lã) e tabaco, e da importante criação ganadeira (ver, entre outros, os dados aportados por Garavaglia, 1983: 161-165; Sarreal, 2014: 87), os jesuítas do Paraguai desenvolveram uma consistente estratégia de ocupação territorial, analisada por: Barcelos, 2013: 212 et seq.

20 Alonso de la Peña Montenegro ao rei. Quito, 4-VII-1662. AGI, Quito, 77, nº 83, f. 1v; cf. El fiscal Nicolás Polanco de Santillana. Lima, 31-VII-1663. AGI, Lima, 102, ff. 2v, 5.

21 Uma carta do Superior Viva esclarece que Fritz não descera aos domínios lusitanos porque estava doente, mas porque seguia ordens para que instalasse novos pueblos a leste e tratasse com seus companheiros portugueses do Colégio de São Luís do Maranhão um eventual auxílio mútuo nessa obra de evangelização. El P. Francisco Viva al P. Rentería. Jeberos, 15-IX-1687. ARSI, NR et Q, 15, i, ff. 133-134, max. f. 134. 
rey de España como otras muchas provincias"22. Por sua vez, da Audiência de Quito, em 1711, o mesmo jesuíta recebeu a seguinte evasiva: "las cajas reales no están para gastos y que es muy difícil el remitir gente a países tan distantes y de clima tan opuesto a el de la sierra" 23 .

São numerosas as evidências do ceticismo do poder central sobre as missões amazônicas. Os missionários estavam orientados pelas autoridades da capital do vice-reinado a abandonar as missões caso lusitanos ou ingleses intentassem alguma invasão. No que os jesuítas não pareciam estar de acordo, como escreveu o padre Uriarte: "De Lima nos aconsejan: nos retiremos; pero somos soldados, que deben guardar su puesto" 24 .

O próprio soldo do governador de Maynas era considerado exorbitante e injustificável $^{25}$. Esse posto existia desde 1618, ano em que o vice-rei do Peru nomeou Diego Vaca de Vega "capitán general de la provincia de Maynas", título mantido por seus sucessores $^{26}$. A rigor, os governadores recebiam um salário de dois mil pesos de prata e residiam em Quito, não nas terras baixas, que raramente visitavam, contentando-se com deixar um tenente delegado na cidade fronteiriça de San Francisco de Borja ${ }^{27}$.

Os jesuítas alertavam para os riscos de os governadores não atenderem à sua obrigação de defender as fronteiras, como quando as missões ficavam à mercê de incursões lusitanas que, sob pretexto de procurar índios fugidos de suas fazendas, importunavam os nativos de Maynas ${ }^{28}$. Seus apelos parecem ter sido ouvidos pelo poder central. Diante de uma ofensiva dos portugueses à província de Omaguas, uma Real Cédula de 1715 lembrou aos encomenderos sua obrigação de acudir à defesa da fronteira. O governador de Maynas, tendo-se recusado a conduzir as tropas que a situação requeria, foi exonerado do cargo ${ }^{29}$.

Os jesuítas chegaram a propor que o governo de Maynas fosse extinto, e que o salário de dois mil pesos fosse utilizado em benefício dos religiosos ${ }^{30}$. Em que pese o valor do soldo fosse elevado, os atrasos em seu pagamento podiam estender-se por

22 Fritz, 1997 [1686-1723]: 100. No entendimento do vice-rei do Peru, a incômoda presença dos portugueses na Colônia do Sacramento, instalada diante de Buenos Aires, em 1680, era um problema mais urgente. Conde de la Monclova al Rey. Lima, 14-IX-1692. AGI, Lima, 89.

23 Fritz, 1997 [1686-1723]: 150. Anos antes, o governador de Loja reagira com indiferença ante a tomada da missão de Omaguas pelos portugueses, segundo verificou um missionário, "por parecerle la tierra de los omaguas de costosa manutención y sin ningún rendimiento inmediato". Wenceslao Breyer a su hermano. La Laguna, 18-VI-1699, in: Matthei, 1969, vol. I: 250.

24 Manuel de Uriarte a Joseph Agustín (seu irmão), Omaguas, 4-X-1762. Lilly Library at the Indiana University [Estados Unidos da América] (doravante Lilly Library), Uriarte Mss., Folder 1760-1765, f. 2.

25 Dionisio de Alcedo y Herrera ao rei. Quito, 15-V-1731. AGI, Quito, 137, $\mathrm{n}^{\circ}$ 3, f. 2; Plan y relación de todas las situaciones salarios y sueldos a misioneros en las cajas de Quito. Quito, 20-V-1740. AGI, Quito, 134, nº 43a, f. 16; Gómez González, 2011: 161.

26 Outorgado pela primeira vez em Callao, a 17 de setembro de 1618, permitia distribuir índios Maynas e Jívaros em encomiendas. Ver transcrição em: Revista de archivos y bibliotecas nacionales, 1899: 180-187.

27 Memorial de Francisco Luis, procurador dos jesuítas. Madrid, 1709. AGI, Quito, 158, ff. 227-228v, max. f. 227v; Manuel Rubio de Arevalo, ex-presidente da Audiência de Quito. Quito, 22-V-1745. AGI, Quito, 127, f. 16; Pedro Vaca de la Cadena, pelo ano de 1642, dirigia a província desde Loja. Jouanen, 1941, vol. I: 356 et passim.

28 Carta do padre Juan Bautista Sana ao Superior Samuel Fritz. Santa Maria Mayor de Yurimaguas, 26-XII-1707. AGI, Quito, 158, ff. 212-213, $\max$. f. 212v.

29 Real Cédula para o presidente e ouvidores da Audiência de Quito. Buen Retiro (Madrid), 14-X-1715. AGI, Quito, 113, n 52, ff. 197-202v. Para o posto foi escolhido Luis de Iturbide, capitão que comandara as tropas de 1709 contra os lusitanos. Título de governador. Buen Retiro (Madrid), 28-XII-1715. AGI, Quito, 113, nº 79, ff. $300-305 \mathrm{v}$

30 O Consejo de Indias mostrou-se favorável aos jesuítas: Parecer del señor fiscal. Madrid, 21-VII-1742. AGI, Quito, 158, ff. 572-578, $\max$. f. 575. O visitador Riofrío preferia que o dinheiro custeasse quatro funcionários 
$\operatorname{anos}^{31}$. O costume de conceder encomiendas em Quito estimulava a residência do governador não em Maynas, mas naquela capital ${ }^{32}$.

A distância e a esterilidade do país eram usadas pelos governadores como justificativas para o alto soldo e para o fato de não residirem em San Francisco de Borja. Mantimentos, como carne salgada, azeite e farinha, vinho para consagrar missas, e o mais necessário à vida humana, deviam ser conduzidos desde as cidades de Loja, Jaén, Cuenca e Quito, localizadas a mais de 150 léguas $^{33}$-observava um governador antes de solicitar dispensa desse emprego $0^{34}$.

A presidência de Quito estava de acordo em deixar de pagar um salário tão elevado aos governadores ${ }^{35}$. Os jesuítas foram exitosos em chamar a atenção do poder central para as terras baixas ameaçadas pelos portugueses, na medida em que, a partir de meados do século XVIII, a Audiência de Quito passou a nomear apenas um justiça maior, com salário de 500 pesos, a título de governador interino, ao passo que os missionários passaram a contar com uma importante remuneração anual, assinalada nas caixas reais ${ }^{36}$.

Entretanto, o ceticismo sobre a presença espanhola na Amazônia continuou vigente por um bom tempo. Que os lusitanos se empenhassem por adquirir territórios cujos benefícios a extrair eram no mínimo duvidosos, ao passo que os custos demandados para defendê-los, esses sim eram certos e consideráveis, apenas causava perplexidade entre as autoridades coloniais de Lima e de Quito. A expedição dirigida por Luis de Iturbide em agosto de 1709, que capturou seis portugueses que importunavam os jesuítas de Maynas, terá custado ao Real Erário 14 mil pesos e, segundo notaram os missionários, promoveu toda a sorte de roubos e depredações nos pueblos, sem resguardar nem mesmo as mulheres dos índios cristãos ${ }^{37}$. O presidente de Quito, Dionisio de Alcedo y Herrera, chegou a referir-se a essa expedição como uma despesa inútil de recursos da Real Hacienda ${ }^{38}$.

que realmente residissem nas missões. Informe do visitador Diego de Riofrío y Peralta. Madrid, 15-VI-1746. AGI, Quito, 191, f. 10v.

31 Memorial de Luis de Iturbide, governador de Maynas. Quito, anterior a 1723. AGI, Quito, 137; Informe de Juan Antonio de Toledo. Quito, 2-VII-1738. AGI, Quito, 137.

32 Real Cédula al gob.or de Popayán. Buen Retiro (Madrid), 14-X-1715. AGI, Quito, 113, nº 49, ff. 191-192v; Visto do fiscal sobre o segundo memorial de Luis de Iturbide, Madrid, 1-VI-1723. AGI, Quito, 13. Niclutsch observou que o posto era comprado em Madrid ou recebido como mercê real, e que recaía em "hidalgos empobrecidos". Registrou, ainda, que eles não visitavam as missões, salvo para tratar de negócios particulares com os índios. Um governador fez com que mais de cinquenta neófitos conduzissem até Quito "dos grandes barcas, junto con su monstruoso equipaje", sem remuneração alguma. Niclutsch, 2012 [1781]: 148.

33 Memorial de Juan Antonio de Toledo. Escrito em Quito e visto em Madrid, a 18-VI-1736. AGI, Quito, 137, ${ }^{\circ}$ 3, ff. $23-24 v, \max$. f. $23 \mathrm{v}$.

34 Informe de Juan Antonio de Toledo. Quito, 2-VII-1738. AGI, Quito, 137. Seu pedido para que se the pagassem adicionalmente o soldo de capitão foi rechaçado pela Câmara de Índias. La Camara de Yndias. Madrid, 28-VI1736. AGI, Quito, 104; Memorial de Juan Antonio de Toledo. Escrito em Quito e visto em Madrid, a 18-VI1736. AGI, Quito, 137, $\mathrm{n}^{\circ} 3$, ff. 23-24v, $\max$. ff. 22-23v.

35 Dionisio de Alcedo y Herrera ao rei. Quito, 15-V-1731. AGI, Quito, 137, nº 3, f. 2.

36 Após o falecimento do governador Toledo, em 1747, a Audiência passou a nomear apenas um justiça maior como interino. Apuntes de las cosas más memorables, Adan Widman, c. 1762. Universidad Pontificia Comi1las, Biblioteca de la Sede Cantoblanco [Espanha], Colección Pastells, Cuaderno no 108, ff. 49-67, $\max$. f. 49. Expulsos os jesuítas, e com o acirramento da contenda demarcatória com os portugueses, o poder central não hesitou em custear a presença de um governador e de outros funcionários em Maynas, destacando-se a atuação de Francisco Requena.

37 Pablo Maroni ao presidente da Audiência de Quito. Colégio Máximo de Quito, 15-VI-1733. AGI, Quito, 158, ff. 543-544, $\max$. f. 544.

38 Dionisio de Alcedo y Herrera [...] remite los autos que tenía en su poder, sobre la colonia del Gran Pará. Madrid, 18-VIII-1740. AGI, Quito, 158, ff. 504-511, cit. f. 506. 
Não se furtavam os jesuítas a reconhecer as debilidades das reduções do vale do rio Marañón. Mesmo com a falta de apóstolos entre os índios de Maynas, a Companhia continuava a remeter padres para outras regiões, como as missões do Orinoco, mais prósperas e beneficiadas com uma não desprezível criação ganadeira ${ }^{39}$. Em contrapartida, a falta de gado suficiente dificultava a sedentarização dos neófitos da província de Maynas, onde, à época da expulsão, havia 1.013 cabeças de gado vacum e 15.464 ovelhas $^{40}$. Malgrado a inadequação do terreno à pecuária e os ataques de morcegos ${ }^{41}$, algum gado era criado nos pueblos de La Concepción de Jeberos, considerado o mais estável ${ }^{42}$, Santiago de Jitipos ${ }^{43}$ e Andoas ${ }^{44}$.

Para efeitos de comparação, basta ter em conta que os jesuítas deixaram em Mojos, em 1769, um estoque total de 54.345 cabeças de gado ${ }^{45}$. As terras de Mojos, como as de Chiquitos, eram adequadas à criação de gado, ao contrário das áreas inundáveis onde os jesuítas instalaram as missões de Maynas ${ }^{46}$.

Com disponibilidade regular de carne, a sedentarização foi rápida entre os índios de Mojos, mas em Maynas, a caça, a pesca e a coleta -e os aspectos culturais relacionados- seguiram sendo fundamentais. O clérigo visitador Escobar y Mendoza opinava que, na impossibilidade de dispor de gado, os índios "quedan más aficionados a la vida montarás y salvaje, hallándose en el centro de su maior felicidad

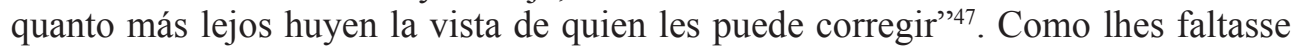
a carne, os neófitos se ocupavam em buscar monos, peixes, pássaros e o que sua flecha alcançava, apartados do governo e da doutrina, em contato com infiéis que lhes forneciam veneno para caça, vivendo errantes e em liberdade para praticar seus antigos costumes ${ }^{48}$.

Para as autoridades coloniais, a região de Maynas não era digna de nota por suas potencialidades econômicas ${ }^{49}$. A esse respeito, Juan Romualdo Navarro, ouvidor da Audiência de Quito, opinava que "son todos estos pueblos por lo común pobrísimos", reduzindo-se seu comércio a alguns tratos de cera, canela, baunilha e resinas, em troca de itens como avelórios, machados, facas, agulhas e outras ferramentas

39 Em 1767, os jesuítas dispunham de várias fazendas de gado nos vales dos rios Casanare e Meta, as quais somavam 44.066 cabeças. Rausch, 1984: 67, 74-75 e 121.

40 Plan de las temporalidades ocupadas a los jesuitas. Quito, 12-V-1769. AGI, Quito, 376, f. 129.

41 Relación de las cosas notables, Juan Magnin. San Francisco de Borja, 6-XI-1743. Archivo Histórico Nacional [Espanha] (doravante AHN), Jesuitas, 251, n 2, d. 3, f. 11.

42 Descripción del país, Francisco Requena. Tabatinga, 12-III-1781. AGI, Quito, 241, nº 58, f. 6v.

43 Testimonio authentico, padre Antonio García de Zeares, Quito, 15-VII-1687. ARSI, NR et Q, 15, i, ff. 139-139v.

44 Francisco Javier Zephyris a Francisco Javier Goettner. Andoas, 10-VII-1727, in: Matthei, 1972, vol. III: 215.

45 Lazaro de Ribera a Antonio Valdez. San Pedro, 5-IX-1788. AHN, Estado, 4555, carpeta 2, nº 5, f. $1 \mathrm{v}$.

46 É preciso relevar que a pecuária era fundamental para o governo jesuíta das missões, como se nota nos casos de Mojos e Chiquitos, onde o estoque ganadeiro diminuiu significativamente após 1768. Cf. as estimativas oferecidas por: Santamaría, 1987: 278-281.

47 Breve noticia de las missiones de los Maynas, Francisco de Escobar y Mendoza. Andoas, 24-I-1769. Real Academia de la Historia [Espanha] (doravante RAH), Colección Mata Linares, t. 3, ff. 221-237.

48 Francisco Javier Zephyris a Francisco Javier Goettner. Pinches, 2-I-1727, in: Matthei, 1972, vol III: 194-195. Os riscos de que a sedentarização fosse evertida também existiam em outras missões. Cf., para o caso de Chiquitos: Relación que antecede, Bispo Francisco Ramón de Herboso y Figueroa. San Ignacio de Chiquitos, 7-I-1769. AGI, Charcas, 515, f. 12v; para as missões do Paraguai: Wilde, 2009: 145-156, 243-257.

49 "La única utilidad para SM en estas tierras que hallo cierta son las muchas almas que con el afán de dichos misioneros se salban”. Carta del gobernador de Quijos, Juan Basabe y Urquieta, remitiendo al Consejo un Informe. Macas, 1-V-1754. AGI, Lima, 1580, f. 8. 
usadas para "domesticar" os índios. E os custos de transporte excediam às vantagens comerciais que tais itens pudessem $\operatorname{ter}^{50}$.

Com efeito, os jesuítas chegaram a ter dúvidas sobre a viabilidade das reduções de Maynas. Em 1640, a hierarquia superior da Companhia emitiu ordens para abandonar aquele empreendimento. Diante dessa notícia, chefes Jeberos foram à cidade fronteiriça de Borja requerer a continuidade da missão, e alegaram que nos últimos anos haviam construído igreja, casa e o mais necessário, e que se tudo fosse abandonado, os nativos "se bolberian a vivir entre las fieras de los montes" 51 . Uma consulta com o padre Provincial, realizada a 5 de dezembro de 1641, deliberou sobre o tema. Concordaram que a missão era viável, sob a condição de que a Companhia tivesse o curato de Borja, que com seus proventos permitiria dar algum socorro aos missionários, além de servir de base para comerciar com as cidades circunvizinhas. Como não houvesse outra religião interessada, o bispo de Quito acedeu ao pedido dos jesuítas ${ }^{52}$.

Não parece demasiado pretender que, no momento em que a ameaça portuguesa se concretizara, em fins do século XVII e princípios do seguinte, a região mereceu maiores atenções das autoridades espanholas. Em certo sentido, passava a cobrar validade a famosa tese do historiador Herbert Eugene Bolton, segundo a qual os missionários podiam servir como um braço do império espanhol nas fronteiras, ao atuarem como exploradores e agentes diplomáticos; defensores dos limites territoriais; agentes que advogavam pela expansão da fronteira; e responsáveis por integrar os índios na comunidade espanhola ${ }^{53}$.

As autoridades coloniais não podiam permanecer inertes diante da penetração de súditos de outros impérios. Era preciso protestar, pois a omissão, o silêncio e a indiferença podiam ser interpretados como um consentimento, como havia sucedido com a invasão dos portugueses sobre as missões de Omaguas, respondida só tardiamente pelos espanhóis ${ }^{54}$. Assim, os protestos contra a penetração de estrangeiros no território implicavam em definir quais as fronteiras desse território: a invasão inimiga acabava por chamar a atenção para uma região até então vista de forma negligente pelas autoridades. Em todo o caso, a mudança de visão era lenta e reversível ${ }^{55}$. Assim, em 1731, o presidente de Quito, informado pelos jesuítas de que os portugueses construíam uma fortaleza no vale do rio Napo, preferiu esgotar os meios diplomáticos antes de enviar uma expedição militar para desalojá-los, alegando não ser lícito responder nos mesmos termos esse "desafuero y provocación" 56.

Entretanto, paulatinamente, pode-se notar que a competição territorial entre lusitanos e espanhóis nas áreas confinantes da Amazônia mudara a visão dos fiscais do Consejo de Indias a respeito daqueles domínios. Já em 1715, uma consulta recomendou a fortificação da fronteira, para o que autorizava lançar mão dos recursos das

50 Idea del reino de Quito, Juan Romualdo Navarro. Madrid, 12-II-1761. AGI, Quito, 223.

51 Figueroa, 1904 [1661]: 53.

52 Jouanen, 1941, vol. I: 355-356.

53 Bolton, 1917: 51-52. Em uma Real Cédula de 1706, os índios Guarani do Paraguai foram qualificados pela Coroa da seguinte forma: "que siendo como son los indios de unas y otras reducciones, presidiarios y fronterizos de enemigos de mi R.l Corona, combenía se mandase a los gov.res y sus tenientes, no los saquen de sus reducciones sin precisa necesidad de mi R.1 servicio". Real Cédula dada a instancias del padre Francisco Burgés. Madrid, 26-XI-1706. AGI, Charcas, 175, ff. 275-277.

54 Gómez González, 2011: 76.

55 Para alguns exemplos, ver: Herzog, 2015: 37-39.

56 Dionisio de Alcedo y Herrera a José Patiño, Quito, 28-V-1731. AGI, Quito, 374, f. 5. 
caixas reais, contanto que os ministros fossem informados com detalhe. Recomendava, ainda, o aumento do número de jesuítas, e que os encomenderos das cidades próximas não fossem dispensados de sua obrigação de servir à sua custa na defesa das regiões liminares ${ }^{57}$.

A nova orientação materializou-se, no ano seguinte, com o início do pagamento regular, aos missionários de Maynas, de um sínodo de 200 pesos anuais a cada religioso $^{58}$. Em 1722, a Coroa autorizava o envio de mais missionários, malgrado o procurador dos inacianos não haver incluído, em seu memorial, os pareceres das autoridades americanas próximas ${ }^{59}$. As invasões portuguesas e a resposta militar dirigida pelo capitão Iturbide, sucedidas há pouco tempo -a disputa fronteiriça sur le terrain-, haviam chamado a atenção da Coroa espanhola para as suas possessões amazônicas.

Os jesuítas foram os grandes responsáveis por atrair os olhos da Coroa espanhola para o que sucedia na Amazônia ocidental. Madrid não podia deixar de requerer aos lusitanos - na opinião do Superior padre Julián- que não adiantassem estabelecimentos, como o forte que planejavam no vale do rio Napo, e que cessassem as hostilidades, especialmente a captura de índios sob o pretexto de que vinham fugidos das terras portuguesas ${ }^{60}$.

\section{Origens dos recursos}

A própria Companhia de Jesus terá financiado -segundo informação do padre Lucas de la Cueva- o início das reduções e os vinte primeiros anos delas ${ }^{61}$. A iniciativa do Colégio de Quito, que teria arcado sozinho, por um bom tempo, com a manutenção de até dez missionários e o custeio das entradas, ficou registrada na memória dos inacianos, que décadas depois assinalaram que as missões foram promovidas "con excesivos gastos [...] sin aver suplicado a V. Magestad estipendio alguno para ellas, animando a todo el buen logro de la predicación en aquellas dilatadas naciones" 62 .

Do mesmo modo, particulares entraram, nos inícios das reduções amazônicas, com importantes donativos. O padre Mercado refere o auxílio financeiro do vice-rei Conde de Alba de Aliste (a instâncias do padre de la Cueva) e dos vecinos de Lima; a remessa de um situado de Loja no valor de 625 patacões, para o sustento dos que presentemente se achavam no vale do Amazonas; e a oferta de toda a sorte de doações (limosnas) por parte dos limenhos, incluindo vários quintais de ferro e de aço, 500 machados, agulhas e outros itens. As missões foram ainda presenteadas com umas 20 campanas, frascos, livros e mais de dois mil pesos de prata lavrada em lustres, cálices, candelabros e vasos ${ }^{63}$.

57 Consulta do Consejo de Indias. Madrid, 13-VI-1715. AGI, Quito, 103, f. 7v.

58 Real Cédula al Presidente y Audiencia de Quito. Madrid, 31-XII-1716. AGI, Quito, 113, nº 93, ff. 351-354v; Real Cédula a los oficiales R.s de Quito. Madrid, 31-XII-1716. AGI, Quito, 113, nº 94, ff. 355-358.

59 Memorial de Pedro de Ocampos de la Compañía de IHS [anterior a 1726], e Consulta do Consejo de Indias. Madrid, 13-XI-1722. AGI, Quito, 190.

60 Juan Bautista Julián ao rei. La Laguna, 12-I-1731. AGI, Quito, 158, ff. 178-180v, max. f. 180.

${ }_{61}$ Memorial do padre Lucas de la Cueva. Quito, c. 1666. AGI, Quito, 20A, nº 32, f. 1v.

62 Instancia solicitando se mantengan posesiones de jesuitas, Manuel Rodríguez, procurador. Madrid, 1682. AHN, Diversos-Colecciones, 27, $\mathrm{n}^{\circ}$ 50, f. 1 .

63 Mercado, 1957 [1684], vol. IV: 220. Sobre o financiamento das missões de Mojos, nos primeiros anos, a cargo das fazendas dos colégios jesuíticos, de importantes donativos de pessoas particulares e de remessas da Coroa: 
Apesar da alegação dos jesuítas de que o financiamento inicial correu por conta da Companhia e de particulares, é certo que a Real Hacienda não tardou em injetar recursos naquela fronteira. As inversões, contudo, deram-se de forma esporádica, e só a partir de 1716 os padres passaram a contar com um ingresso regular das caixas reais (Tabela 1$)$.

Tabela. 1. Contribuições reais para as missões de Maynas, 1660 a $1707^{64}$.

\begin{tabular}{|c|c|c|c|c|}
\hline Ano & Valor $^{\mathbf{6 5}}$ & Justificativa & Fonte pagadora & Fontes \\
\hline $\mathbf{1 6 6 0}$ & 1.000 & Ajuda de custo & Caixa Real de Quito & (a) \\
\hline $\mathbf{1 6 6 7}$ & $475^{66}$ & Ajuda de custo & Caixa Real de Quito & (b) \\
\hline $\mathbf{1 6 7 0}$ & $400^{77}$ & Doutrina de Archidona & Caixa Real de Quito & (c) \\
\hline $\mathbf{1 7 0 7}$ & 4.000 & Ajuda de custo & Vacante do bispo de Quito & (d) \\
\hline
\end{tabular}

Pela década de 1660, discutia-se o pagamento de uma côngrua anual aos religiosos que atuavam no Marañón. O já mencionado parecer do bispo de Quito, emitido em 1662, aderia à proposta de que a Coroa provesse os missionários jesuítas da Amazônia com a côngrua de 300 a 400 pesos ao ano. E em caso de Sua Majestade aprovar o sínodo, era de parecer o mesmo ministro evangélico que deveria ser com a condição de que se submetessem à jurisdição episcopal; e que dessem início à cobrança do tributo e do dízimo ${ }^{68}$. Sugestões que não foram bem recebidas no Consejo de Indias, por contrariarem, de resto, a prática do império espanhol em regiões de fronteira, onde os índios reduzidos somente passavam a pagar tributos quando bem fundados os alicerces da missão e verificada a existência de empreendimentos econômicos viáveis.

Durante o século XVII, portanto, os jesuítas de Maynas permaneceram desprovidos de uma ajuda regular do poder central, e a única disposição favorável nesse sentido foi incluída em uma cédula de 1670. Efetivamente, como os inacianos se encontravam na posse do curato de Archidona desde 1660 (eles seriam substituídos em $1685)^{69}$, a Coroa assinalou a remuneração de 400 pesos, com a prudente isenção de dízimos e tributos, pois se “podía recelar q' los indios, viéndose grabados, se ausentarían la tierra adentro y se perderían las almas de los reducidos, como sucedía aun

Vargas Ugarte, 1964, t. 3: 30-31; Real Cédula a la Audiencia de Charcas. Madrid, 31-XII-1698. AGI, Lima, 407; Diego Cristóbal Mesia, presidente da Audiência de Charcas. Plata, 3-IX-1690. AGI, Charcas, 25, r. 5, nº 22, f.

2. Para as missões de Chiquitos: Consulta del Consejo de Indias. Madrid, 15-X-1716. AGI, Charcas, 169, f. 3v.

64 Fontes: Elaboração própria a partir dos seguintes dados: (a) Real Cédula para os oficiais da Real Hacienda da cidade de Quito. Madrid, 28-VIII-1660. AGI, Santa Fe, 983; Real Cédula ao bispo de Quito. Madrid, 30-VIII1660. AGI, Quito, 77, $\mathrm{n}^{\circ}$ 83c; (b) Carta de los oficiales reales de Quito [...] a S.M. Quito, 21-II-1667. AGI, Quito, 20A, no 32; Carta do vice-rei Conde de Lemos. Lima, 10-XII-1669. AGI, Lima, 68, liv. 6, n 11; (c) Real Cédula a la Audiencia de Quito. Madrid, 21-IV-1670. AGI, Quito, 210, lib. 4, ff. 127-131v, cit. f. 130; Real Cédula para os oficiais da Real Hacienda da cidade de Quito. Madrid, 21-IV-1670. AGI, Santa Fe, 983; (d) Visto do Fiscal do Consejo de Indias ao Memorial de Antonio de Quiros, procurador da Companhia de Jesus. Madrid, 5-X-1709. AGI, Quito, 189, f. 609v; Real Cédula ao presidente da Audiência de Quito. Madrid, 16-XII-1709. AGI, Santa Fe, 983.

65. Em pesos de 8 reales.

${ }^{66}$ A serem pagos anualmente, mas não consta por quantos anos.

67 O mesmo do anterior.

68 Alonso de la Peña Montenegro ao rei. Quito, 4-VII-1662. AGI, Quito, 77, nº 83, f. 1v.

69 Jouanen, 1941, vol. I: 486. 
con menos causa" ${ }^{90}$. Parece que a Coroa pretendia controlar mais de perto a entrega de recursos aos padres, pois repreendeu os ouvidores da Audiência por terem fornecido ajuda de custo ao padre Lucas de la Cueva sem confirmação de Madrid $^{71}$. Com isso, o poder central esperava que os inacianos tivessem mais recursos para prover as reduções de "índios bárbaros" do vale do rio Marañón ${ }^{72}$. O parecer do Consejo de Indias, que fundamentou essa Cédula, afirmava que a miséria da terra justificava as isenções de dízimo e tributo, "por ser toda arcabuco muy cerrado y no tener más frutos que los silvestres, con que se sustentan". Maynas era um território de missões de "índios bárbaros" semelhante ao Chaco: com escassas expectativas de vantagens comerciais e de rápida adoção da polícia europeia, os gastos da Coroa eram um mal necessário para defender a fronteira e uma forma de cumprir a incontornável obrigação do Real Patronado ${ }^{73}$. Ao que parece, com o término do período dos jesuítas como curas de Archidona, deixaram de contar com o sínodo destinado àquele curato, o qual, na opinião do procurador Manuel Rodríguez, permitira consideráveis melhoras "de policía y habilidades de los indios, de ornamentos en las iglesias y estar establecidas algunas cosas convenientes" 74 .

Os procuradores da Companhia esmeravam-se em compor memoriais prolixos e bem documentados, inclusive com o recurso a mapas impressos, em seu empenho de convencer o Consejo de Indias a direcionar recursos para o financiamento das missões. Em seu memorial de 1708, que voltava a requerer a côngrua anual, o procurador Antonio de Quiros disse que o grosso dos gastos corria à custa das fazendas e fábricas dos mesmos jesuítas. À diferença de outros informes, Quiros pintava um quadro promissor: referia a propensão dos índios para a aceitação do cristianismo, sua constância na nova religião, a raridade de revoltas e apostasias ${ }^{75}$. Seu memorial estava acompanhado de um mapa e uma planta impressos, onde constavam pontualmente as reduções e o número dos nativos convertidos, como notou o fiscal que cuidava do assunto e que, em seu parecer, sugeriu fosse o suplicante atendido com recursos das rendas vacantes de outros bispados do Peru ${ }^{76}$.

Era recorrente utilizar como exemplo as missões de Mojos e Paraguai para obter benefícios semelhantes para Maynas ${ }^{77}$. Pelo ano de 1703, Juan Martínez de Ripalda, procurador geral das províncias de Santa Fé e Quito, reclamou um sínodo anual para os missionários. Seu argumento era o de que os jesuítas que trabalhavam nas terras baixas da Amazônica deveriam receber tratamento uniforme, e que concessões

70 Real Cédula a la Audiencia de Quito. Madrid, 21-IV-1670. AGI, Quito, 210, lib. 4, ff. 127-131v, cit. f. 130; cf. Real Cédula para os oficiais da Real Hacienda da cidade de Quito. Madrid, 21-IV-1670. AGI, Santa Fe, 983.

71 Real Cédula a la Audiencia de Quito. Madrid, 21-IV-1670. AGI, Quito, 210, lib. 4, ff. 127-131v, $\max$. f. 131.

72 Rodríguez, 1990 [1684]: 494.

73 Real Cédula al Presidente de la Audiencia de Quito. Madrid, 21-IV-1670, in: Ibidem: 382.

74 Ibídem: 494.

75 Memorial de Antonio de Quiros, procurador da Companhia de Jesus. Madrid, 1708. AGI, Quito, 189, f. 2.

76 Visto do fiscal. Madrid, 5-X-1709. AGI, Quito, 189, f. 610. O ano em que o memorial foi lido em Madrid sugere que o mapa, pelo menos, podia tratar-se daquele elaborado e impresso pelo jesuíta Samuel Fritz em Lima, em 1707. Sobre os trabalhos cartográficos do padre Fritz, ver: Almeida, 2003; Dias, 2012.

77 A analogia é lembrada na própria cédula que concedeu o sínodo para os religiosos do Marañón: Real Cédula aos oficiais da Audiência de Quito. Madrid, 31-XII-1716. AGI, Santa Fe, 983. Em princípios da década de 1690, os jesuítas estavam impacientes com a falta de sínodo para as missões. O padre Marbán expressou esse sentimento ao Provincial Francisco Javier, em carta de 20 de março de 1690: "Yo no sé por qué estas misiones no han de gozar del sínodo de que gozan todas las demás misiones de la Compañía; ¿siempre habremos de ser soldados voluntarios?". ARSI, Perú, 21, f. 111 apud Vargas Ugarte, 1964, t. 3: 54. 
semelhantes haviam sido dadas em recente cédula de 16 de janeiro de 1702 aos religiosos da Califórnia, do Orinoco e de $\operatorname{Mojos}^{78}$.

\section{O sínodo anual dos missionários}

Mas foi somente a partir de 1716 que os jesuítas passaram a contar com um financiamento regular por parte da Real Hacienda. A Real Cédula de 31 de dezembro de 1716 autorizou a entrega de 200 pesos anuais, sem exigência de captação de tributo algum sobre os índios do Marañón. Ora, na visão da Coroa, tratavam-se de "índios bárbaros" em território estratégico, o que justificava o investimento. Visava, portanto, fomentar as reduções, dispensando os padres de impor vexações aos neófitos, "sin tener q.' cuidar de buscar medios para su sustento, sino solo a procurar no se malogre mies q.' ofrece tan colmados frutos"

Não se deve diminuir a importância da ação coordenada dos procuradores jesuítas em Madrid. A formulação de um discurso uniforme em torno da defesa da fronteira e a capacidade logística da Companhia de manter seus procuradores diante do Consejo de Indias, sempre providos de novos informes, seguramente influíram na decisão final. Pois as três missões que a Companhia mantinha nas franjas da Amazônia, onde a presença lusitana se fazia a pouco e pouco mais incômoda, receberam precisamente no mesmo ano de 1716 a autorização da Coroa para cobrarem uma côngrua anual nas caixas da Real Hacienda. O ano de 1716 foi, portanto, crucial na história das missões de Maynas, Mojos e Chiquitos. Para os missionários de Mojos, a Real Cédula de 12 de outubro de 1716 atendeu ao que pedia o procurador Francisco de Rotalde e concedeu um sínodo de 200 pesos anuais ${ }^{80}$. A Consulta do Consejo de Indias que definiu o sínodo de 200 pesos data de 25 de agosto de 1716 . Esse tribunal levou em conta que os jesuítas conseguiram um consistente adiantamento daquelas missões, tendo a Real Hacienda invertido até então apenas 10 mil pesos ${ }^{81}$. Também em 1716, uma Real Cédula beneficiou as missões de Chiquitos, em atenção ao pedido do procurador Bartolomé Ximénez, e concedeu 200 pesos anuais a cada missionário ${ }^{82}$.

O exame das contas das caixas reais de Quito permite ter a dimensão do peso que tinha, no orçamento daquela jurisdição, o pagamento do sínodo anual autorizado em 1716 aos religiosos de Maynas. Se se toma o mapa da receita e despesa para o ano de 1731 como ideal, pode-se dizer que aquela caixa real gastava $44 \%$ de sua receita com situados para Cartagena; $23 \%$ com soldos de ministros; $3 \%$ com o soldo do governador de Maynas; e 2\% com os sínodos dos missionários daquelas missões. Os $24 \%$ restantes estariam divididos em gastos menores (o valor total das despesas, no mencionado ano, foi de 97.174 pesos). Para as missões da Companhia, o montante

78 Memorial de Juan Martínez de Ripalda. Madrid, anterior a 1703. AGI, Quito, 189, ff. 599-601.

79 Real Cédula aos oficiais da Audiência de Quito. Madrid, 31-XII-1716. AGI, Santa Fe, 983. Grupos recém-reduzidos deviam contar com "la piedad y liberalidad" da Coroa. Consulta del Consejo de Indias sobre la instancia de don Bartolomé Ximénez, de la Compañía de IHS. Madrid, 15-X-1716. AGI, Charcas, 169, f. 6v; Cf. Liv. 2 , Tít. 2, Lei 8 $8^{\text {a }}$ in: Recopilación, 1943 [1681], t. 1: 233.

80 Vargas Ugarte, 1964, t. 3: 57.

81 Consulta del Consejo de Indias sobre la instancia de Francisco Rotaldo, de la Compañía de IHS. Madrid, 25VIII-1716. AGI, Charcas, 169.

82 Minuta da Real Cédula à Audiência de Charcas. Madrid, 17-XII-1716. AGI, Charcas, 178. O processo de negociação do sínodo para Chiquitos foi analisado por: Tomichá Charupá, 2002: 176-181; para Chiloé, ver: Moreno Jeria, 2007: 311-313, 320, 339, 345 y 351. 
total era de 2.200 pesos, ou seja, o suficiente para pagar 11 missionários com 200 pesos cada. Acresça-se que o sacerdote de Borja vencia 330 pesos, e o governador de Maynas, que não residia na província, 2.757 pesos $^{83}$. Já o mapa de 1740 permite conhecer que $8,76 \%$ dos gastos com soldos assinalados nas caixas de Quito iam para as regiões de fronteira. Tudo o que era gasto com salários somava 98.552 pesos. Nesse montante, os gastos com missões de jesuítas e franciscanos e com os governadores das áreas fronteiriças alcançavam 8.635 pesos $^{84}$.

Ao mesmo tempo, a partir da década de 1740, as missões de Maynas foram em grande medida financiadas por ingressos provenientes das fazendas de Cancagua, Yaruquí (que contava com uma obraje), Caraburo y Urapanta. Na administração dessas e de outras fazendas e obrajes, que possuíam na província de Quito, os jesuítas perseguiam, tanto quanto possível, os objetivos de lucro, reinversão e continuidade, pois uma parte importante dos recursos era gasta com a manutenção dos colégios, o transporte de missionários desde a Europa e as atividades missionárias. Os resultados, contudo, não eram animadores. O complexo de fazenda, rancho e fábrica têxtil fornecia milho, cevada, batata e feijão para as caixas de Quito, mas os custos de produção, dependente de mais de 100 trabalhadores, tornava os lucros diminutos. Estima-se que o lucro do moinho alcançasse pouco mais de 600 pesos por ano ${ }^{85}$. É preciso notar que, em Quito, os jesuítas esforçavam-se por expandir seus negócios com as obrajes ${ }^{86}$. Em 1741, chegaram a solicitar autorização para dispor de mais teares nas suas fábricas, reguladas por convenções corporativas. O Consejo de Indias não via com bons olhos essa novidade, já que podia significar que, sendo o gado ali consumido o dos próprios jesuítas, ou seja, isento de alcabala, sofreria a Real Hacienda uma perda considerável ${ }^{87}$.

As dificuldades de financiar o trabalho de evangelização na Amazônia levaram os jesuítas a direcionarem seus esforços em propor reformas para o estado atual das coisas. O padre Andres de Zárate, já em 1735, apresentava ao Consejo de Indias uma pauta de reinvindicações que, no seu entender, fomentariam a expansão da Santa Fé Católica entre aqueles nativos. Era preciso que o poder central autorizasse o envio de mais 60 missionários; que o sínodo de 200 pesos em espécie fosse comutado em desconto nos tributos das haciendas; que o governador de Maynas residisse em Borja; que vencesse metade dos dois mil pesos, e o restante fosse empregado em expedições que atraíam os nativos; e que fosse fundada uma vila de espanhóis o mais próximo possível da cidade do Pará $^{88}$.

A solicitação para comutar o pagamento dos sínodos em espécie por descontos nos tributos que suas haciendas pagavam por seus índios era uma demanda fundamental dos inacianos, e era decorrente da centralidade dos empreendimentos jesuíticos na manutenção das missões. O tema foi retomado, em 1741, pelo procurador Thomas Nieto Polo, que lembrava que, como o sínodo era pago em gêneros de pouca estimação, não raro com atrasos, o procedimento corrente resultava em danos à em-

83 As maiores fontes de ingressos na jurisdição da Audiência de Quito eram os tributos, 25.882 pesos, e as alcabalas, 12.087. Como o valor total da receita para 1731 foi de 73.559 pesos, houve déficit. Mapa y resumen general de la R.1 Haz.da de la Caja R.1 de Quito. 25-III-1731. AGI, Quito, 131, nº 70a.

84 Plan y relación de todas las situaciones salarios y sueldos a misioneros en las cajas de Quito. Quito, 20-V-1740. AGI, Quito, 134, n $43 \mathrm{a}$, f. $17 \mathrm{v}$.

85 Cushner, 1982: 58, 87, 93, 160-161 e 190.

86 Expediente sobre la compra de un obrage. Quito, 1718. AGI, Quito, 189.

87 Visto do fiscal sobre um memorial de Thomas Nieto Polo. Madrid, 14-XI-1741. AGI, Quito, 190.

88 Ynstrucción que deberán observar los Padres, Andres de Zárade. Quito, 30-VII-1735. AGI, Quito, 190. 
presa missionária. Entretanto, em seu parecer, o fiscal do Consejo de Indias não abria mão de que os recursos entrassem primeiro nas caixas da Real Hacienda, para que só então fosse paga a remuneração dos missionários ${ }^{89}$.

Mais de um observador atentou para as dificuldades que diziam respeito à remuneração dos padres. Em seu informe de 1746 sobre a visita que realizara às missões, Diego de Riofrío sugeriu reformar o sistema de financiamento. Àquela época, havia em Maynas 24 pueblos e um total de 7.780 almas $^{90}$. O visitador verificara a importância dos itens como ferramentas, avelórios e outros, para ganhar os índios da floresta e manter seu ímpeto pelo trabalho, uma vez reduzidos ${ }^{91}$. Mas os sínodos estavam atrasados e os recursos próprios dos jesuítas não fluíam com regularidade, pois a fazenda que possuíam em Tumbaco fora danificada por uma erupção vulcânica. Assim, Riofrío propunha três medidas pera reformar esse estado de coisas. Primeiro, em vez de pagar dois mil pesos ao governador de Maynas, convinha pôr um justiça maior à frente da jurisdição, com soldo de 400 pesos, e acrescentar o restante ao sínodo dos missionários. Segundo, parecia-lhe acertado desmembrar a região do Napo e seus afluentes do governo de Maynas e agregá-la ao de Quijos, cujo governador podia mais facilmente visitá-la. Finalmente, era preciso atender à reivindicação dos jesuítas: a comutação do sínodo em descontos nos tributos e taxas devidos pelos empreendimentos jesuíticos. Com isso, esperava-se evitar os atrasos e facilitar a aquisição do material necessário para as reduções ${ }^{92}$.

Apesar das diversas vozes em favor da alteração das formas de financiamento das missões, o poder central não parece ter inovado a esse respeito. Expulsos os jesuítas, franciscanos e clérigos seculares alternaram períodos em que estiveram a cargo dos pueblos ${ }^{93}$. A partir de 1778, aos custos de manutenção dos curas se somaram as despesas com a Quarta Partida de Demarcação espanhola, que atuou em conjunto com a sua homóloga portuguesa ${ }^{94}$. As dificuldades em torno do pagamento dos sínodos, contudo, permaneceram. Passadas várias décadas, Francisco Requena, ex-governador e então assessor do Consejo de Indias, observava que os 200 pesos eram abonados a cada sacerdote em caixas muito distantes de Maynas, de difícil e larga viagem, de modo que eles recebiam já passados dois anos de sua residência, devendo valer-se de procuradores para cobrá-los ${ }^{95}$.

89 Memorial de Thomas Nieto Polo de la Compañía de IHS. Madrid, anterior a 13-XI-1741. AGI, Quito, 190, 1v. De certo modo, os religiosos advogavam em favor de um sistema semelhante ao que já existia em Chiquitos, onde os 200 pesos, ao que parece, nunca foram diretamente pagos aos missionários. Relación informativa, Francisco Ramón de Herboso, bispo de Santa Cruz de la Sierra. San Ignacio, 7-I-1769. AGI, Charcas, 515, f. 18. No Paraguai, segundo apurou o estudo de Sarreal (2014: 86), o sínodo de 466 pesos e 5 reales, assinalado para cada missão, era pago aos jesuítas por meio da dedução do que deviam em tributos e taxas.

90 Informe do visitador Diego de Riofrío y Peralta. Madrid, 15-VI-1746. AGI, Quito, 191.

91 “....] así como son fáciles de atraher, y hacerlos salir de sus ocultas grutas, y reducirlos a poblado, por una pieza de herramienta, asimismo aun hallándose entablados, y doctrinados, si les faltan los dones, y regalillos dichos, se ausentan, y desamparan a los misioneros". Ibidem, f. 10.

92 Ibidem, ff. 10v, 12v, 14. Cf. ainda as reflexões de Jouanen sobre o informe de Riofrío: Jouanen, 1943, vol. II: 483.

93 Sobre Maynas pós-jesuítico, ver, entre outros, Medina Rojas, 1999.

94 Sobre o impacto da presença das partidas demarcatórias no território em questão, ver o estudo recente de: Santos, 2016.

95 Francisco Requena, ministro del Consejo, [...] evacua el informe que se le pidió. Reus, 15-IV-1807. AGI, Lima, 1580, f. 1v. 


\section{O comércio dos itens produzidos nas missões}

Um dos principais fatores que agravavam os referidos problemas residia no fato de os jesuítas jamais terem conseguido instalar, na Amazônia, um sistema produtivo viável. Já em 1660, a Coroa reconhecia não ser possível esperar rendimentos importantes daquelas terras ${ }^{96}$. Há indícios, contudo, de que os jesuítas procuraram comercializar certos itens produzidos em Maynas. A visitação do padre Provincial Rodrigo de Barnuevo, realizada em 1644 por seu delegado, padre Andrés de Artieda, estava especialmente instruída a investigar três queixas que pesavam contra os jesuítas: a primeira, a de que se ausentavam dos pueblos sem justificativa plausível; a segunda, a de que tais ausências serviam para comerciar com o sal de Paranapura, paragem próxima aos Jeberos, e para cuidar das fazendas que possuíam em Moyobamba; e a terceira, a de que sacavam ouro do rio Cangasa, nas terras dos Jívaros. O visitador apurou que os religiosos não se ausentaram mais do que em três oportunidades; que era certo que praticavam algum comércio de sal; mas, quanto ao ouro, não havia provas de que os jesuítas o extraíssem de parte alguma ${ }^{97}$.

Como quer que seja, parece certo que alguns pueblos negociavam diretamente com particulares das cidades espanholas vizinhas. Assim, por exemplo, o pueblo de Omaguas obtinha recursos com a produção e exportação de ferramentas e outros itens. Os interessados remetiam ferro e outras matérias-primas à missão e recebiam de volta os produtos trabalhados pelos artesãos, a saber, machados, correntes de ferro, facas, redes etc. Segundo o padre Uriarte, que descreveu como era feito esse comércio, os índios não aceitavam chapéus como pagamento ${ }^{98}$.

Do mesmo modo, havia alguma exportação de produtos através dos chamados "despachos". A cada seis meses eram enviadas algumas canoas a Quito, onde as missões eram providas do mais necessário. Chegou-se a buscar socorro, também, em Lamas e Moyobamba. Os poucos efeitos exportados incluíam cera branca, baunilha e outras coisas de pouca entidade, que se entregavam ao procurador das missões. Este enviava desde Quito a provisão de vinho, farinha para hóstias, vestido interior e sotainas para os missionários, alguma quantidade de tecido e porção de ferro para ferramentas, facas, correntes, anzóis e outros itens usuais. Um produto muito buscado era o veneno utilizado para as caçadas, chamado de curare, que chegava a Maynas a partir do pueblo de San Ignácio de Pebas ${ }^{99}$. Índios Ticunas e Pebas, além de outros grupos intermediários, obtinham ferramentas em transações que envolviam um extenso tráfico de curare, dentro e fora da província ${ }^{100}$.

Em que pese as suspeitas de colonos e funcionários, as vantagens de semelhante comércio, para os inacianos, eram limitadas. As cidades espanholas circunvizinhas, como Riobamba e mesmo Quito, na opinião do padre Breyer -que escrevia em

96 Real Cédula aos oficiais da Real Hacienda da cidade de Quito. Madrid, 28-VIII-1660. AGI, Santa Fe, 983, f. 1v. Comparativamente, os franciscanos se viram em maiores dificuldades por estarem desprovidos de empresas similares às da Companhia. Fray Manuel de Cisneros al rey. Quito, 19-IV-1711. AGI, Quito, 200, ff. 838-839v.

97 Jouanen, 1941, vol. I: 359. Mais tarde, entre 1728 e 1730, acusações semelhantes exigiram a atenção de outro visitador, padre José Gutiérrez, da mesma Companhia, que preparou um informe secreto sobre o assunto, minutado em: Ibidem, 1943, vol. II: 431.

98 Pedro Schoneman a Manuel de Uriarte. Santa María, 26-IX-1762. Lilly Library, Uriarte Mss., Folder 17601765.

99 Chantre y Herrera, 1901 [anterior a 1801]: 616-618.

100 Cipolletti, 1988: 534. 
1699-, ofereciam pouco pelos produtos que os padres enviavam e pediam demasiado por aqueles que entregavam ${ }^{101}$.

Em seus escritos do exílio, o padre Velasco refletia sobre as razões que teriam levado os jesuítas a não desenvolver o comércio de Maynas como esperado. As exportações reduziam-se a algum pano de algodão, cera, cacau, resina, veneno para caça e tabaco ${ }^{102}$. A estudiosa Sandra Negro acrescenta a essa relação a canela e as hamacas ou redes ${ }^{103}$. Outros produtos que, apesar de seu alto valor econômico, não foram aproveitados adequadamente incluíam bálsamos, gomas, azeites, mel e baunilha. Nem mesmo o açúcar e o café introduzidos pelos padres puderam animar o limitado comércio. A responsabilidade por esse estado de coisas Velasco atribuía à relação problemática estabelecida pelos próprios jesuítas: "la mayor parte de las naciones indianas no sabe lo que es comercio, porque estaban acostumbradas a que los misioneros las proveyesen de herramientas y de cuanto habían menester". Esse tipo de tutela não apenas não garantia a provisão de recursos para as missões, como também não alentava esforços para aproveitar das riquezas naturais: "dejan perderse muchísimas cosas que podían traficarse con gran utilidad, o porque no tienen cómo excitarlas o más bien porque, contentos con poco o nada, se dejan llevar de su innata pereza" 104 .

A produção de exportação nunca foi estabelecida de modo sustentável. Daí a dependência não apenas do sínodo de 200 pesos anuais, mas também de outras remessas de auxílios das caixas reais. A Coroa, ao contribuir com três quartos do orçamento (se estão certas as estimativas de Golob), convertia Maynas em uma missão diferente das de Guaranis, Mojos e Chiquitos, um empreendimento estratégico em boa parte financiado pelo situado. Para custear o quarto restante do orçamento das reduções, os jesuítas captavam donativos e utilizavam parte dos lucros de suas fazendas ${ }^{105}$.

Acresça-se a essas dificuldades a de que os índios não saíam a buscar produtos da floresta sem que fossem devidamente remunerados. O padre Uriarte refere que, no pueblo de San Pablo de Iquitos do rio Napo (onde passou a residir a partir de 1754), para recolher a cera, os índios práticos nesse negócio deviam ausentar-se por duas semanas, e que, para entregá-la, pediam, por cada três libras, um machado, e por uma libra, uma faca. A cera era em parte utilizada nas igrejas, e em parte comercializada em Quito e em Lamas, onde eram obtidos os artigos necessários para as missões ${ }^{106}$. Outra forma de obter a cooperação dos índios consistia em alegar que a missão necessitava de objetos litúrgicos e lançar sobre os paroquianos uma derrama voluntá-

\footnotetext{
101 Wenceslao Breyer a su hermano. La Laguna, 18-VI-1699, in: Matthei, 1969, vol. I: 254.

102 Velasco, 1981 [1789]: 544-545.

103 Negro, 1999: 188.

104 Velasco, 1981 [1789]: 544-545. Apesar do ceticismo do padre Velasco, o exame de outros documentos mostra uma grande variedade de itens exportados pelas missões de Maynas. Além dos referidos acima pelo cronista inaciano e pela historiadora Sandra Negro, outras fontes indicam também a remessa de: óleo de copaíba, cana, coco, limões, sebo, salsaparrilha, urucu, mel, farinha de mandioca, ají (pimento), pimento seco, estoraque, ouro em pó, grãos, cascarilla (casca do fruto de uma euforbiácea [Croton eluteria]) e madeira (Cf. Magnin, 1998 [1740]: 197; La Camara de Yndias, f. 3v: Minuta do informe do ex-presidente Dionisio de Alcedo y Herrera. Madrid, 22-VI-1739. AGI, Quito, 104; Descripción de la Provincia de Quito. Año de 1754, Marquês de Salva Alegre. Quito, 13-IX-1754. AGI, Quito, 220, n 1, ff. 52v-53; Autos. Quito, 12-V-1791, f. 12; Declaração de José Checa y Barba. Quito, 16-VIII-1791. AGI, Quito, 342).

105 Golob, 1982: 229-231.

106 Uriarte, 1986 [1775]: 524 et passim
} 
ria, entrando cada um com sua possibilidade e com a cera que pudesse recolher nos bosques, cujo produto, uma vez vendido em Quito, permitia importantes aquisições para a igreja ${ }^{107}$.

O Consejo de Indias desistiu de impor o tributo aos índios de Maynas, missões que continuaram a ser, em sua maior parte, custeadas pela Coroa. Os jesuítas apresentaram à Real Audiência de Quito solicitações para postergar o início dessa cobrança, dado não haverem encontrado um produto em que fixar ou estabelecer o tributo em Maynas. Argumenta Chantre y Herrera, com base em relatos de missionários, que com não pequeno trabalho e subidos custos de transporte a província exportava cacau a Quito, mas os preços não podiam competir com os de outras regiões. À baunilha sucedia o mesmo problema, em razão dos fretes de sua condução a Lima ou Cartagena. Quanto à cera, embora abundante, sua coleta era um processo moroso que exigia a ausência do índio por pelo menos três meses (se quisesse voltar com três ou quatro libras de cera), em cujo tempo não assistia à doutrina cristã, não ouvia missa, nem atendia à sua família ${ }^{108}$. Considerando esses fatores, um parecer do fiscal do Consejo de Indias (o cronista jesuíta não menciona a data) concluía que era inviável incluir os neófitos de Maynas entre os índios tributários ${ }^{109}$. Outro aspecto que pesou em favor da isenção de tributos foi a obrigação dos índios em servir militarmente em defesa das missões. As companhias de milicianos, mandadas por oficiais indígenas nomeados pelo governador, defendiam a província contra índios revoltosos, infiéis e escravistas portugueses, além de promoverem as entradas e o estabelecimento de novos pueblos ${ }^{110}$.

Até o momento da expulsão, os jesuítas não descansaram em sua busca por um produto cujo valor econômico permitisse um salto de qualidade na situação das missões amazônicas ${ }^{111}$. Inicialmente, tentaram promover a exportação de "carne de vaca marina" ou peixe-boi ${ }^{112}$. O padre Francisco Viva depositou suas esperanças na baunilha, a qual considerava que, em breve, poderia permitir o custeio dos itens solicitados pelos índios ${ }^{113}$. Em proposta entregue ao visitador Altamirano, em 1689, manifestava seu intento de passar à Europa assim que obtivesse 20 mil pesos e 500 libras em baunilha e cascarilla, a fim de custear o recrutamento de 40 sujeitos (em princípio italianos) e de dois navios com povoadores para a Amazônia ${ }^{114}$.

107 Chantre y Herrera, 1901 [anterior a 1801]: 657.

108 Ibídem: 628.

109 Ibídem: 629.

110 Ibídem: 630. Uma diferença importante das missões de Maynas em relação às outras missões amazônicas de Mojos e Chiquitos residia em que, nestas últimas, os índios passaram a pagar tributo à Coroa por volta da metade do século XVIII, ao passo que os nativos do Marañón continuaram isentos até o fim da mencionada centúria. Esse aspecto revela a precariedade das missões de Maynas em comparação com as suas congêneres instaladas no oriente da atual Bolívia. Os Chiquitos, por exemplo, passaram a pagar tributo desde 1748, um peso por cada índio, taxa que incidia sobre 2.914 tributáveis, em cujo montante se descontava os 200 pesos assinalados a cada um dos 14 religiosos, com o que, em três anos, gerou um saldo favorável de 342 pesos para a Real Hacienda. Minuta da Real Cédula ao vice-rei do Peru, Buen Retiro (Madrid), 19-I-1751. AGI, Charcas, 189.

111 Em Mojos e Chiquitos, a obsessão com a promoção de produtos tropicais como cacau, algodão, madeiras, azeites, gomas, resinas, bálsamos, cera de abelhas, baunilha, anil, etc., continuou após a expulsão dos inacianos, como mostra o trabalho de: Santamaría, 1987: 261-262 e 281-287.

112 El P. Samuel Fritz da noticia al P. R.or de Quito. San Joaquín, 22-VI-1686. ARSI, NR et Q, 15-i, ff. 117-118, $\max$. f. 117.

113 El P. Francisco Viva al P. Rentería. Xeveros, 15-IX-1687. ARSI, NR et Q, 15, i, ff. 133-134, cit. f. 133.

114 Propuesta del P. Fra.co Viva hecha en la ciudad de Pasto al P. Diego Fra.co Altamirano. Pasto, XII-1689. ARSI, NR et Q, 15, i, ff. 230-233v, $\max$. f. 231. 
Os jesuítas também tentaram expandir a produção de canela a partir do pueblo de Andoas: "tenían una gran huerta de canelos cultivados", informa alguém, "y de ellos sacavan anualmente crecida porción de canela que beneficiada por los yndios naturales de aquellas misiones". Em 50 dias a canela colhida em Andoas podia chegar a Lima ${ }^{115}$.

Já o padre Zárate, em seu informe de 1739, preferia sugerir que se desse atenção à miríade de produtos que as missões podiam produzir, e que, uma vez assentado seu comércio, permitiriam a consolidação da presença espanhola. Esses artigos incluíam, além do cacau, da baunilha, da cera e dos outros já mencionados, alguns itens pouco lembrados pelos cronistas: cañafístula, almendra, gengibre, anil, escobilla, carabiru, copal, azeite de Maria, caraña, guayusa e sal ${ }^{116}$.

\section{A falta de missionários}

A falta de missionários era outro problema estrutural das reduções amazônicas, que os jesuítas jamais puderam contornar. Os marinheiros astrônomos Jorge Juan e Antonio de Ulloa referem que, em 1681, havia 21 pueblos em Maynas, os quais estavam a cargo de apenas quatro religiosos: eram eles, Juan Jiménez, Francisco Fernández, Pedro de Cáceres e Lorenzo Lucero ${ }^{117}$. Em 1668, havia apenas oito padres naquelas missões; a situação piorou em 1684, quando somente atuavam ali cinco missioná$\operatorname{rios}^{118}$. No século XVII, rara vez passou de sete ou oito o número de missionários nas missões ${ }^{119}$. Consequência da falta de ministros, os que ali serviam estavam sobrecarregados de trabalho. Pela década de 1670, não havia missionário em Maynas que não respondesse por pelo menos três pueblos ${ }^{120}$. Em meados do século seguinte, um fiscal do Consejo de Indias reconheceu que, dada a extensão da província, era impossível que fosse bem assistida se não contasse com pelo menos 90 missionários ${ }^{121}$.

Em relação ao envio de missionários para a América espanhola, era decisivo o papel do procurador, que recebia os pedidos de religiosos das províncias e intermediava, junto ao Consejo de Indias, a licença para que passassem ao Novo Mundo e a ajuda de custo necessária para fazê-lo. Transportar missionários era sumamente custoso. Era preciso arcar com os gastos de deslocamento, hospedagem, manutenção diária, objetos litúrgicos, livros e outros itens, que podiam alcançar até dez ducados por missionário ${ }^{122}$. Estimava-se, em 1692, que para mandar 60 sacerdotes eram precisos 1.791.240 maravedís de prata ${ }^{123}$. Essa despesa era coberta pela Real Hacienda

115 Explicación del árbol de la Canela, frei Francisco Alvarez de Villanueva. Colegio de Santa Rosa de Ocopa, 1788. AGI, Lima, 1610, $\mathrm{n}^{\circ}$ 4, ff. 78-85, cit. f. 80v. Outras ordens religiosas estavam atentas à existência de canela no vale do Ucayali: Ynstrucción del Padre Guardián de Ocopa, fray Manuel Sobreviela. 1792. AGI, Lima, 1580, f. 12v.

116 Ynforme que haze a S.M. el P. Andres de Zarate de la Compañía de IHS. Madrid, 28-VIII-1739. AGI, Quito, 158 , ff. 273-297, $\max$. f. 296v.

117 Juan - Ulloa, 1985 [1747], vol. II: 296, viii, §49.

118 Catálogo de 1668. ARSI, NR et Q, 3, f. 250; Catálogo de 1684. ARSI, NR et Q, 3, ff. 349v-353v, 358-358v.

119 Jouanen, 1941, vol. I: 520.

120 Ibídem: 478.

121 Parecer do fiscal do Consejo de Indias. Madrid, 22-XI-1751. AGI, Quito, 191, f. 2v.

122 Martínez-Serna, 2009: 201.

123 Contaduría. Madrid, 8-X-1692. AGI, Quito, 90, nº 29. 
com desconto nos direitos dos navios que seguiam para as Índias ${ }^{124}$. Mas os procuradores deviam estar atentos e ser suficientemente persuasivos para convencer as autoridades a arcar com o custo da totalidade dos religiosos solicitados. O padre Richter, por exemplo, informou-se em Madrid de que, "por los gastos demasiado altos, solo se concederían doce cada tres o cuatro años, hasta alcanzar el número cuarenta. Para cada misionero se calcula dos mil télaros a razón de gastos de viaje"125.

Os procuradores da Companhia de Jesus eram particularmente conhecidos por sua insistência e sua preocupação com temas econômicos e com a circulação de informações, pessoas e bens. Seus memoriais revelavam uma eficaz rede de informações que conectava os procuradores em Madrid com as necessidades financeiras e de pessoal das diversas missões do Novo Mundo ${ }^{126}$.

Uma das estratégias mais comuns consistia em contornar o processo moroso que envolvia a solicitação de mais operários, o qual determinava que fossem agregados os pareceres do vice-rei, do presidente da Audiência, do bispo, do governador e de outras autoridades. Em não poucos memoriais enviados pelos jesuítas, essa falta era compensada com argumentos que visavam sensibilizar o Consejo de Indias ${ }^{127}$. Um memorial que pedia 60 religiosos para o Paraguai compensou a falta dos pareceres com notícias de martírios e outras mortes "por las excesivas fatigas, y trabajos, que padecen en tanta variedad de climas". Embora o fiscal tivesse indeferido o pedido, o Consejo de Indias o contrariou e autorizou o envio de 30 padres, mandando advertir que os próximos memoriais viessem justificados ${ }^{128}$. Além disso, os procuradores esmeravam-se em apresentar argumentos que relevavam a urgência do socorro solicitado, a exemplo do padre Altamirano que, em 1746, enfatizou a disposição dos inacianos de trabalhar além de seus limites, pois sendo necessários 54 padres para atender doze "nações bárbaras" do rio Beni, pedia somente $30^{129}$.

Mesmo assim, pode-se estimar que de cada dez missionários solicitados pelos procuradores para a região aqui estudada, quatro desembarcavam no Novo Mundo: dos 749 missionários solicitados entre 1674 e 1760, foram recebidos $303(40,45 \%)$ (Figura 2). Um contingente equiparável ao que passou ao Reino de Chile (326), mas muito abaixo do que foi ao Rio da Prata (879), e inferior ao de missionários que chegou ao Novo Reino de Granada (486) ${ }^{130}$. Uma perda importante ocorreu, contudo, em 1717, quando o navio Sangronis, que levava 25 missionários, naufragou ${ }^{131}$.

124 Real Cédula para os oficiais da Real Hacienda da cidade de Popayán. Madrid, 21-I-1717. AGI, Santa Fe, 983. Para mais detalhes: Real Cédula a instâncias de Juan Bautista Mujica, procurador da Companhia de Jesus. Real Sitio de San Ildefonso, 11-IX-1723. AGI, Santa Fe, 983.

125 Enrique Richter a Bartolomé Cristelio. San Miguel de Ibarra, 18-VIII-1685, in: Co, 2007: 60-62.

126 Martínez-Serna, 2009: 182.

127 Entre os principais casos, confrontar: Memorial de Pedro de Ocampos de la Compañía de IHS. Madrid, anterior a 1726, e Consulta do Consejo de Indias. Madrid, 13-XI-1722. Ambos em: AGI, Quito, 190; Visto do Fiscal. Madrid, 13-IV-1722. AGI, Charcas, 382; Consulta do Consejo de Indias. Madrid, 8-VI-1733. AGI, Charcas, 383. Um exemplo de parecer que recomendava negar o pedido de auxílios feito por franciscanos em: José de Araujo y Río, presidente da Audiência, ao rei. Quito, 18-X-1739. AGI, Quito, 134, nº 10, f. 1.

128 Consulta do Consejo de Indias sobre o memorial de Antonio Machón, procurador da Companhia. Madrid, 8-VI1733. AGI, Charcas, 383.

129 Memorial del padre Pedro Ignacio Altamirano de la Compañía de Jesús, procurador de Indias. Madrid, 9-IX1746. AGI, Lima, 540. O visto do fiscal foi favorável: Visto del Sr. Fiscal. Madrid, 2-X-1746. AGI, Lima, 540; cf. Pedro de Herrera, 24-III-1747. AGI, Lima, 540.

130 Galán García, 1995: 364.

131 Memorial del P. Juan Francisco de Castañeda, procurador de la Compañía de Jesús. Escrito em Madrid e visto pelo Consejo de Indias na mesma cidade em 10-V-1720. AGI, Quito, 189, nº 9; Galán García, 1995: 296. 


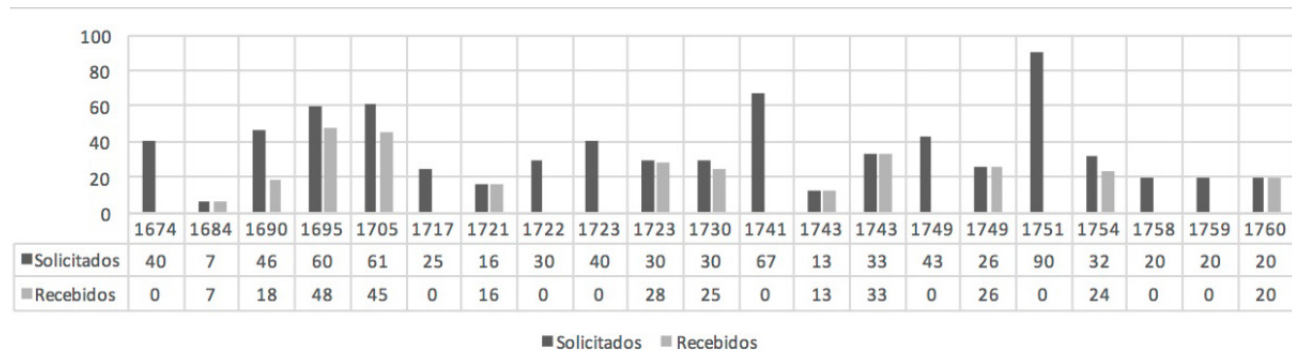

Figura 2. Missionários solicitados e recebidos pela província jesuítica de Quito ${ }^{132}$.

Outro problema recorrente era a diversão de missionários inicialmente destinados a uma região, à qual não chegavam por terem sido desviados para o serviço em outra parte. Em 1723, dois religiosos que deviam ter ido para o Marañón foram remetidos a Chocó ${ }^{133}$. Assim, era comum que uma província tomasse alguns missionários destinados a outra: em 1659, uma missão de 24 sujeitos foi dividida pelo Provincial Hernando Cabero da seguinte forma: nove escolares, que ainda não eram sacerdotes, foram enviados a Quito, e o restante permaneceu na província de Novo Reino de Granada ${ }^{134}$. A política territorial da Coroa também influía no destino dos jesuítas. As Reais Cédulas de 1688 e 1693 autorizaram que, dos 61 religiosos destinados para Quito e Santa Fe, 18 fossem redirecionados para as novas fundações de Santo Domingo ${ }^{135}$. A Coroa ainda autorizou o presidente da Audiência do Panamá a requerer ao de Quito quantos missionários fossem necessários para as novas reduções de sua jurisdição ${ }^{136}$.

Não deixa de ser surpreendente a diferença entre o número de jesuítas residentes no Colégio de Quito e nas missões de Maynas, como indicam os dados dos Catálogos da Província ${ }^{137}$. Já uma carta ânua de 1660 afirmava que nove missionários residiam em Maynas, ao passo que no Colégio de Quito viviam 68 sujeitos $^{138}$. O ano mais desfavorável foi o de 1684, quando cinco religiosos estiveram em Maynas e 86 no Colégio de Quito; o mais favorável, o de 1761, com 29 religiosos nas missões,

132 Fontes: Elaboração própria a partir de dados que aparecem, de um lado, nos memoriais apresentados pelos procuradores, em que solicitavam religiosos, e de outro, nos pareceres do Consejo de Indias, Reais Cédulas e registros de missionários que embarcaram para o Novo Mundo, localizados nos seguintes legajos: AGI, Contratación, 5548 (1674, 1684, 1690, 1695, 1705, 1717, 1721, 1723, 1730, 1741, 1743, 1749, 1754, 1760); AGI, Quito, 4 (1674); AGI, Quito, 90 (1695); AGI, Quito, 189 (1722); AGI, Quito, 190 (1722, 1730, 1741); AGI, Quito, 191 (1749, 1751); AGI, Quito, 192 (1758, 1759); AGI, Santa Fe, 403 (1690); AGI, Santa Fe, 983 (1674, 1684). Os resultados foram cotejados com os trabalhos anteriores de Aspurz, 1946: 278 et seq. (Apéndice I); Borges Morán, 1977: 511-524; Galán García, 1995: 197 et seq. Não estão incluídos, aqui, os pedidos e concessões destinados unicamente ao Novo Reino de Granada.

133 Real Cédula a instâncias de Juan Bautista Mujica, procurador da Companhia de Jesus. Real Sitio de San Ildefonso, 11-IX-1723. AGI, Santa Fe, 983; Real Cédula a instâncias de Pedro de Campos, procurador dos jesuítas. San Lorenzo de El Escorial, 6-X-1726. AGI, Contratación, 5548, nº 2, r. 5 (5), ff. 9-9v.

134 Velasco, 1941 [1788]: 300.

135 Domingo López de Calo Mondragón ao Juiz Fiscal. Madrid, 22-IX-1704. AGI, Contratación, 5548, nº 2, r. 4, f. 10 .

136 Memorial de Thomas Nieto Polo, S.J. Madrid, anterior a 8-V-1741. AGI, Quito, 190.

137 Os catálogos consultados encontram-se em: ARSI, NR et Q, legajos: 3, 5, 7 e 11; Archivo Histórico de la Provincia Toledana de la Compañía de Jesús, [Espanha], estante 2, caja 82 bis, 1460, 45 (1 e 2); nas reproduções de outros arquivos que facilita: Piñas Rubio, 2011.

138 Relación annua de la Provincia del Nuevo Reyno de Granada desde el año de 1655 hasta el año de 1660. Santa Fe, 20-II-1660. ARSI, NR et Q, 13, i, f. 3. 
embora residissem 93 no Colégio. Um ano típico foi o de 1723, com 12 nas missões e 65 no Colégio ${ }^{139}$. Para todo o período, em média, houve em Maynas uma dúzia de missionários, que atendiam a duas dúzias de pueblos, enquanto que no Colégio de Quito a média de residentes era de 65 religiosos $^{140}$. Nas missões de Chiquitos, no oriente da atual Bolívia, entre 1724 e 1767, houve uma média de 28 jesuítas para sete pueblos, ou seja, dois por pueblo, quase a proporção inversa de Maynas ${ }^{141}$.

Em 1740, os mencionados Juan e Ulloa observaram que, de cada 20 jesuítas que chegavam a Quito, somente um era destinado a Maynas: as haciendas e obrajes de Quito provinham ingressos à Companhia, as missões somente ocasionavam gastos $^{142}$. Nota-se, portanto, que os jesuítas de Quito, diante o famoso dilema entre privilegiar o Colégio ou as missões, optaram por concentrar-se no primeiro. Se é certo que o Consejo de Indias nem sempre aprovava o número de missionários que os jesuítas solicitavam, e que a Real Hacienda tardou em assinalar uma côngrua anual que garantisse aos padre das terras baixas amazônicas os recursos mais urgentes, parece igualmente certo que os jesuítas preferiam manter a maioria dos religiosos no Colégio de Quito, capital em que os inacianos contavam com importantes haciendas e obrajes, ao passo que destacavam apenas o mínimo necessário para o trabalho de evangelização na floresta.

Embora os custos do envio de jesuítas europeus fossem consideráveis, a Companhia via com reservas a possibilidade de empregar americanos nas missões fronteiriças, algo que o vice-provincial Juan Martínez Rubio justificava "por la poca aplicación q.' los naturales tienen a profesar su instituto"143. É certo, porém, que americanos atuaram na Amazônia, ainda que em minoria, como se nota pelo auto de entrega dos inacianos expulsos aos portugueses do Pará: havia 19 jesuítas em Maynas, sendo 11 deles estrangeiros e quatro americanos ${ }^{144}$.

Por outro lado, a falta de religiosos que padeciam as províncias jesuíticas da Espanha, especialmente em fins do século XVII e princípios do seguinte, impunha à Companhia a necessidade de justificar a presença de estrangeiros nas missões ${ }^{145}$. Uma Real Cédula de 12 de março de 1674 autorizou o envio de religiosos estrangeiros, desde que provenientes dos Estados hereditários da Casa de Áustria e limitados a uma terça parte de cada expedição ${ }^{146}$. Para o período entre 1674 e 1760 , nota-se que os jesuítas avançaram pouco sobre essa margem, pois dos 303 religiosos enviados, 119 eram estrangeiros (cerca de 40\%) ${ }^{147}$. Entretanto, a política dos jesuítas de privilegiar o Colégio de Quito, em detrimento das missões, ao reter, por consequência, um número maior de estrangeiros no colégio, desagradava o Consejo de Indias, que

139 Catálogo de 1684. ARSI, NR et Q, 3, ff. 359v-353v e 358-358v; Catálogo de 1723, ff. 155-158 e 161v-162v, reproduzido em Piñas Rubio, 2011; Catálogo de 1761. ARSI, NR et Q, 7, ff. 5-13 e 25-27.

140 Média simples obtida a partir dos dados aportados por: Piñas Rubio, 2011, "Estadística general".

141 Cf. Tomichá Charupá, 2011: 347.

142 Juan - Ulloa, 1985 [1747], vol. II: 285, viii, §11-13.

143 Representación a S.M. por el P. Juan Martínez Rubio. Santa Fe, 8-II-1691. RAH, Jesuitas, t. 218, d. 11. Sobre a preferência dos jesuítas por empregar europeus nas missões, ver: Aspurz, 1946: 234, 274.

144 Autos da entrega dos padres jesuítas dos domínios espanhóis. Vila de Olivença do Rio Solimões, 8-XII-1768. Arquivo Histórico Ultramarino [Portugal], Pará, cx. 66, d. 5708, ff. 1-4v, max. ff. 2v, 3v.

145 Consejo de Indias. Madrid, 28-VIII-1715. AGI, Quito, 103, f. 54; Aspurz, 1946: 235-236 e 242; Borges Morán, 1977: 250-252.

146 Resumen de los decretos, consultas y memoriales de Juan Martínez de Ripalda de la Compañía de IHS. Madrid, 7-VII-1702. AGI, Santa Fe, 403. O privilégio seguiu válido sob os Bourbons.

147 Cf. as fontes da Figura 2. 
afirmou, em um parecer, que não era obrigação do monarca financiar tão custosa viagem, se não fosse para que missionassem entre os "índios bárbaros", e mandou avisar ao procurador da Companhia "que no pasen los extranjeros que propone y declare quantos van dedicados para misiones de los demás y a estos se les asista"148.

\section{Considerações finais}

Em 1716, a Coroa espanhola decidiu financiar regularmente as missões jesuíticas na Amazônia. Até então, havia prevalecido o ceticismo das autoridades locais e mesmo dos jesuítas, que não encontravam caminhos para viabilizar a produção de itens de alto valor lucrativo naquelas regiões.

Os jesuítas, por meio de seus procuradores, foram fundamentais para a mudança de visão do poder central. Diante das invasões portuguesas, que se intensificaram em fins do século XVII e princípios do seguinte, os procuradores inacianos compareceram assiduamente ao Consejo de Indias em Madrid, com seus memoriais em que solicitavam fosse assinalada uma côngrua anual regular e enviados mais missionários para um território considerado estratégico.

A decisão de 1716 não foi, de modo algum, isolada. Naquele mesmo ano a Coroa autorizou o pagamento de sínodos para as missões fronteiriças que confinavam com as possessões lusitanas na bacia amazônica: Maynas, Mojos e Chiquitos. Constituiu, portanto, parte de um programa mais amplo de consolidação da soberania territorial castelhana na América do Sul. Vale lembrar que os portugueses haviam instalado a Colônia do Sacramento em 1680; nas décadas seguintes, chegaram a Madrid notícias de que lusitanos palmilhavam as missões de Chiquitos e Mojos, vindos de São Paulo e do Pará; por fim, a situação das missões do Paraguai de modo algum era confortável, e os jesuítas puderam capitalizar os serviços dos seus neófitos Guaranis como milicianos para obter novas concessões da Coroa ${ }^{149}$.

Embora o poder central estivesse convencido da importância da defesa da Amazônia ocidental para salvaguardar as áreas produtoras de metal precioso no Peru e em Nova Granada aos contrabandistas portugueses, no plano local o empreendimento seguiu sendo visto com ambiguidade. As autoridades coloniais eram relutantes em enviar soldados e povoadores, e os próprios jesuítas, ainda que recebessem continuamente missões com novos religiosos vindos da Europa, resistiam a enviá-los para a fronteira.

Assim se verifica que a contradição entre as escassas vantagens econômicas imediatas e a importância estratégica da Amazônia ocidental acabou por limitar o desenvolvimento das missões jesuíticas naquela região. A Companhia de Jesus em momento algum aceitou abrir mão da sua jurisdição sobre aquele vasto território, e os religiosos que atuavam sur le terrain empenharam-se em buscar itens de alto valor econômico que pudessem tornar aquelas missões autossuficientes.

A rigor, contudo, em âmbito amazônico, o dilema entre optar pelo Colégio ou pela missão foi resolvido pelos inacianos em favor do primeiro. A Companhia de Jesus contava, na região de Quito, com numerosas haciendas e obrajes, de modo que o Colégio acabou por reter a grande maioria dos religiosos que o Consejo de Indias havia aprovado, inicialmente, para que passassem como missionários dos índios

\footnotetext{
148 Resumen de los decretos, consultas y memoriales. Madrid, 7-VII-1702. AGI, Santa Fe, 403, f. 5v, 6v.

149 Sobre esses aspectos, ver: Mörner, 1968: 90; Lopes de Carvalho, 2014: 71-72, 254-255 e 380-390.
} 
amazônicos. Além disso, regiões mais promissoras economicamente, como as missões de Nova Granada, desviaram para si recursos humanos que, em teoria, deveriam ter sido recebidos na jurisdição de Quito.

É certo, portanto, que a insistência dos procuradores da Companhia em solicitar recursos defensivos para umas missões amazônicas que, a pouco e pouco, passaram a contar com a incômoda vizinhança dos portugueses, encontrou certa adesão junto ao poder central, preocupado, como estava, em formular uma estratégia defensiva mais ampla para os territórios americanos. Contudo, o programa de consolidação das missões jesuíticas na Amazônia parece ter sido limitado, de um lado, pela especificidade das relações dos religiosos com as populações indígenas locais, e de outro, pelos interesses econômicos da própria Companhia.

\section{Referências bibliográficas}

Almeida, André Ferrand de. "Samuel Fritz and the Mapping of the Amazon". Imago Mundi, $\mathrm{n}^{\mathrm{o}} 55$ (2003), 113-119.

Aspurz, Lázaro de. La aportación extranjera a las misiones españolas del Patronato Regio. Madrid: Consejo de la Hispanidad, 1946.

Bayle, Constantino. La expansión misional de España. Barcelona: Labor, 1936.

- Notas sobre bibliografia jesuítica de Mainas. Madrid: Ediciones Jura, 1949.

Barcelos, Artur Henrique Franco. O Mergulho no Seculum: exploração, conquista e organização espacial jesuítica na América espanhola colonial. Porto Alegre: Animal, 2013.

Block, David. Mission culture on the Upper Amazon: native tradition, Jesuit enterprise, and secular policy in Moxos, 1660-1880. Lincoln: Univ. of Nebraska Press, 1994.

Bolton, Herbert E. "The Mission as a Frontier Institution in the Spanish-American Colonies". The American Historical Review, vol. 23, no 1 (1917), 42-61.

Borges Morán, Pedro. El envío de misioneros a América durante la época española. Salamanca: Univ. Pontificia de Salamanca, 1977.

- "Estructura y características de la evangelización americana". En Historia de la Iglesia en Hispanoamérica y Filipinas, vol. I: Aspectos generales, editado por Borges Morán, Pedro. Madrid: Biblioteca de Autores Cristianos, 1992, 423-435.

Brading, David. "Tridentine Catholicism and Enlightened despotism in Bourbon Mexico". Journal of Latin American Studies, vol. 15, nº 1 (1983), 1-22.

Broggio, Paolo. Evangelizzare il Mondo: le missioni della Compagnia di Gesù tra Europa e America: secoli XVI-XVII. Roma: Carocci, 2004.

Carbonell de Masy, Rafael. Estrategias de desarrollo rural en los pueblos guaraníes (16091767). Barcelona: A. Bosch, 1992.

Chantre y Herrera, José. Historia de las misiones de la Compañia de Jesús en el Marañón español: 1637-1767 [anterior a 1801]. Madrid: Impr. de A. Avrial, 1901.

Cipolletti, María Susana. "El tráfico de curare en la cuenca amazónica (Siglos XVIII y XIX)". Anthropos, vol. 83, no 4/6 (1988), 527-540.

Clossey, Luke. Salvation and Globalization in the Early Jesuit Missions. New York: Cambridge Univ. Press, 2008.

Codina, María Eugenia. "Haciendas y misiones: el caso de Maynas". En Esclavitud, economía y evangelización: las haciendas jesuitas en la América virreinal, editado por 
Negro, Sandra - Marzal, Manuel M. Lima: Pontificia Univ. Católica del Perú, Fondo Editorial, 2005, 243-261.

Cushner, Nicholas P. Farm and factory: the Jesuits and the development of agrarian capitalism in colonial Quito, 1600-1767. Albany: State Univ. of New York Press, 1982.

Dias, Camilla Loureiro. "Jesuit Maps and Political Discourse: The Amazon River of Father Samuel Fritz". The Americas, vol. 69, n 1 (2012), 95-116.

Downes, Peter. "Jesuitas en la Amazonía: experiencias de Brasil y Quito". En La misión y los jesuitas en la América Española, 1566-1767, editado por Hernández Palomo, José Moreno Jeria, Rodrigo. Sevilla: CSIC, 2005, 151-186.

Figueroa, Francisco de. Relación de las misiones de la Compañía de Jesús en el país de los Maynas [1661]. Madrid: Victoriano Suárez, 1904.

Fritz, Samuel. Diario [1686-1723]. Quito: Academia Ecuatoriana de la Lengua, 1997.

Galán García, Agustín. El 'Oficio de Indias' de Sevilla y la organización económica y misional de la Compañía de Jesús (1566-1767). Sevilla: Fundación Fondo de Cultura de Sevilla, 1995.

Garavaglia, Juan Carlos. “Las misiones jesuíticas: utopía y realidad”. En Economía, sociedad y regiones, editado por Garavaglia, Juan Carlos. Buenos Aires: Ediciones de la Flor, 1987, 120-191.

Golob, Ann. "The Upper Amazon in historical perspective". Tesis Doctoral, City University of New York, 1982.

Gómez González, Juan Sebastián. La frontera selvática: historia de Maynas, siglo XVIII. Tesis doctoral, Universidad Nacional Autónoma de México, 2011.

Grohs, Waltraud. Los indios del Alto Amazonas del siglo XVI al siglo XVIII: poblaciones y migraciones en la antigua provincia de Maynas. Bonn: Udo Oberem, 1974.

Grosser, José (ed.). Las misiones de Mainas de la Antigua provincia de Quito de la Compañía de Jesús. Quito: Biblioteca Ecuatoriana “Aurelio Espinosa Pólit”, 2007.

Herzog, Tamar. Frontiers of possession: Spain and Portugal in Europe and the Americas. Cambridge - Massachusetts: Harvard University Press, 2015.

Jouanen, José. Historia de la Compañia de Jesús en la antigua provincia de Quito: 15701773, II vols. Quito: Ecuatoriana, 1941-1943.

Juan, Jorge - Ulloa, Antonio de. Las noticias secretas de América, 2 vols. [1747]. Madrid: CSIC, 1985.

Lane, Kris E. Quito 1599: City and colony in transition. Albuquerque: University of New Mexico Press, 2002.

Lopes de Carvalho, Francismar Alex. Lealdades negociadas: povos indígenas e a expansão dos impérios ibéricos nas regiões centrais da América do Sul (segunda metade do século XVIII). São Paulo: Alameda, 2014.

- "Estrategias de conversión y modos indígenas de apropiación del cristianismo en las misiones jesuíticas de Maynas, 1638-1767'. Anuario de Estudios Americanos, vol. 73, nº 1 (2016), 99-132.

Magnin, Juan. Descripción de la Provincia y misiones de Mainas en el Reino de Quito [1740]. Quito: Biblioteca Ecuatoriana "Aurelio Espinosa Pólit" - Sociedad Ecuatoriana de Investigaciones Históricas y Geográficas, 1998.

Maldavsky, Aliocha. Vocaciones inciertas: misión y misioneros en la provincia jesuita del Perú en los siglos XVI y XVII. Sevilla: CSIC, 2012.

Martínez-Serna, J. Gabriel. "Procurators and the Making of the Jesuits' Atlantic Network". En Soundings in Atlantic history: latent structures and intellectual currents, 1500-1830, 
editado por Bailyn, Bernard - Denault, Patricia L. Cambridge - Massachusetts: Harvard University Press, 2009, 181-209.

Matthei, Mauro (ed.). Cartas e informes de misioneros jesuitas extranjeros en Hispanoamérica, vol. I. Santiago: Pontificia Universidad Católica, 1969.

- Cartas e informes de misioneros jesuitas extranjeros en Hispanoamérica, vol. III. Santiago: Pontificia Universidad Católica, 1972.

Medina Rojas, Francisco de Borja. "Los Maynas después de la expulsión de los jesuitas”. En Un reino en la frontera: las misiones jesuitas en la América colonial, editado por Negro, Sandra - Marzal, Manuel M. Lima: Pontificia Universidad Católica del Perú - AbyaYala, 1999, 299-330.

Mercado, Pedro de. Historia de la Provincia del Nuevo Reino y Quito de la Compañía de Jesús, IV vols. [1684]. Bogotá: Empresa Nacional de Publicaciones, 1957.

Moreno Jeria, Rodrigo. Misiones en Chile austral: los jesuitas en Chiloé, 1608-1768. Sevilla: CSIC - Universidad de Sevilla - Diputación de Sevilla, 2007.

Mörner, Magnus. Actividades políticas y económicas de los jesuitas en el Rió de la Plata: la era de los Habsburgos. Buenos Aires: Paidós, 1968.

Negro, Sandra. "Maynas, una misión entre la ilusión y el desencanto". En Un reino en la frontera: las misiones jesuitas en la América colonial, editado por Negro, Sandra Marzal, Manuel M. Lima: Pontificia Universidad Católica del Perú - Abya-Yala, 1999, 185-206.

Newson, Linda A. Life and death in early colonial Ecuador. Norma: University. of Oklahoma Press, 1995.

Niclutsch, Francisco. Noticias americanas de Quito y de los indios bravos del Marañón [1781]. Quito: Cicame - Fundación Alejandro Labaka, 2012.

Piñas Rubio, Francisco. Catálogo de la provincia de Quito de la Compañía de Jesús en la Colonia: 1586-1767. Alicante: Biblioteca Virtual Miguel de Cervantes, 2011. Rausch, Jane M. A tropical plains frontier: the Llanos of Colombia, 1531-1831. Albuquerque: University of New Mexico Press, 1984.

Recopilación de Leyes de los Reinos de las Indias [1681], 4ª ed., III tomos. Madrid: Consejo de la Hispanidad, 1943.

Reeve, Mary-Elizabeth. "Regional Interaction in the Western Amazon: The Early Colonial Encounter and the Jesuit Years: 1538-1767”. Ethnohistory, vol. 41, nº 1 (1993), 106-138.

Revista de archivos y bibliotecas nacionales, año 2, vol. 3 (1899).

Radding, Cynthia. Landscapes of Power and Identity: Comparative Histories in the Sonoran Desert and the Forests of Amazonia from Colony to Republic. Durham: Duke University. Press, 2005.

Rey Fajardo, José del. Los Jesuitas en Venezuela: Tomo V: las misiones germen de la nacionalidad. Caracas: Universidad Católica Andrés Bello, 2007.

Rodríguez, Manuel. El descubrimiento del Marañón [1684]. Madrid: Alianza, 1990.

Rumazo González, José. La región amazónica del Ecuador en el siglo XVI. Sevilla: Escuela de Estudios Hispano-Americanos, 1946.

Oberem, Udo. Los Quijos: historia de la transculturación de un grupo indígena en el Oriente Ecuatoriano. Otavalo: Instituto Otavaleño de Antropología, 1980.

Santamaría, Daniel. "La economía de las misiones de Moxos y Chiquitos (1675-1810)". Ibero-Amerikanisches archiv, vol. 13, no 2 (1987), 255-295.

Santos, Roberta Fernandes dos. Missões de Maynas: presença territorial missionária e política de fronteira no Marañón (1638-1799). Tesis Doctoral, Pontifícia Universidad Católica de São Paulo, 2016. 
Sarreal, Julia. The Guarani and their missions: a socioeconomic history. Stanford: Stanford University Press, 2014.

Stephan, Jörg. Spanische Herrschaft und Mission in der Grenzprovinz Maynas: 1619-1768. Stuttgart: Heinz, 2000.

Sweet, David. A rich realm of nature destroyed: the Middle Amazon valley, 1640-1750. Tesis Doctoral, University of Wisconsin, 1974.

Taylor, Anne C. "The western margins of Amazonia from the early sixteenth to the early nineteenth century". En The Cambridge history of the native peoples of the Americas: South America, vol. III, parte II, editado por Salomon, Frank - Schwartz, Stuart B. Cambridge: Cambridge University Press, 1999, 188-256.

Tomichá Charupá, Roberto. La primera evangelización en las reducciones de Chiquitos, Bolivia (1691-1767): protagonistas y metodología misional. Cochabamba: Verbo Divino, 2002.

- "Población indígena y diversidad cultural en Chiquitos (siglo XVIII). Algunas consideraciones". En XXV Reunión Anual de Etnología, Museo Nacional de Etnología y Folklore. La Paz: [s.n.], 2011, 331-355.

Uriarte, Manuel Joaquín. Diario de un misionero de Maynas [1775]. Iquitos: Monumenta Amazónica, 1986.

Vargas Ugarte, Rubén. Historia de la Compañia de Jesús en el Perú, tomo III. Burgos: Imp. de Aldecoa, 1964.

Velasco, Juan de. Historia moderna del Reyno de Quito y Crónica de la Provincia de la Compañía de Jesús del mismo Reyno [1788]. Quito: Impr. de la Caja del Seguro, 1941.

- Historia del reino de Quito en la América meridional [1789]. Caracas: Biblioteca Ayacucho, 1981.

Weber, David J. Bárbaros: los españoles y sus salvajes en la era de la Ilustración. Barcelona: Crítica, 2007.

Wilde, Guillermo. Religión y poder en las misiones de guaraníes. Buenos Aires: SB, 2009.

Zubillaga, Felix. "El Procurador de las Indias Occidentales de la Compañía de Jesús". Archivum Historicum Societatis Iesu, Roma, vol. 22 (1953), 367-417. 